\title{
A CRÍTICA DE HEGEL AOS POSTULADOS DA RAZÃO PRÁTICA COMO DESLOCAMENTOS DISSIMULADORES
}

Marcos Lutz Müller*

StNTESE - Este artigo apresenta a critica radical de Hegel na Fenomenologia do Espirito à teologia moral dos postulados da razăo prática kantiana. Hegel cs reconstrót como projeçes resultantes da contradiçáo da consciencla moral, que, ao termo da experiéncia que ela perfaz de st mesma mediante a sua objetivaçăo na "visāo moral do mundo", é compelida a confessar a sua hipocrisia. Depois de uma caracterização sucinta da antinomia e dos postulados da fazdo prática, bem como das principais teses da sua reconstruçăo critica por Hegel (1), analisa-se a contradiçâo da consciência moral, concebida como puro dever, que ê a matriz dos postulados (2), e aborda-se detalhadamente a série de "deslocamentos dissimuladores" (Verstellungen) que articulam cs dualismos e as oposiçojes em que essa contradição fundamental se desdobra, e cuja resolução fepresentativa é projetada nos trếs postulados (3, 4, 5). Por fim mostra-se que o colapso da "visấo moral do mundo" conduz a consciência moral à experiência da sua hipocrisia e à sua superaçẵo na autocerteza moral subjetiva, que antecipa a sua auto-supressão o a superaçăo da moralidade (6).

PALAVRAS-CHAVB - Hegel, critica, razăo prática, Kant.
ABSTRACT - This article presents the critic radical of Hegel in Phenomenology of Spirit to the moral theology of the postulates of the practical reason of Kant. Hegel reconstructs them as resulting projections of the contradiction of the motal conscience, that, to the term of the experience that her realize of herself by means of fts manifestation in the moral vision of the world, is compelled to admit its hypocrisy. After the brief characterization of the antinomy and of the postulates of the practical reason, the well the of the main theses of its critical reconstruction by Hegel (1), the contradiction of the moral conscience is analyzed, concelved like pure obligation, that is main of the postulates (2), and it is approached the serious in full detal of "dissembling displacements" (Verstellungen) that articulate the dualisms and the oppositions in thet that fundamental cootradiction is unfolded, and whose representative resolution is projected in the three postulates $(3,4,5)$. Finally, it is shown that the collapse of the "moral vision of the world" drives the moral conscience to the experience of its hypoctisy and to its overcoming in the subjective moral own-cortainty, that advances its own-suppression and the overcoming of the morality (6).

KBY WORDS - Hegel, Critic, Practical Reason, Kant.

- Doutor em Flosofia. Professor Titular de Filosofla da Universidade de Campinas - unicaMr, Campinas, SP. 


\section{1 - Introduçäo}

A recepçåo critica da doutrina dos postulados da razão pura prática, no sulco da tentativa kantiana de uma fundamentaçăo prática da Metafisica, foi para filosofia pós-kantiana um dos mais importantes filōes embrionários. Essa recepção foi a via de acesso mais freqüente para a discussão dos princípios da fundamentaçăo kantiana da moral e o confronto com a doutrina dos postulados e do sumo bem foi - campo teórico privilegiado para Fichte, Schelling e, principalmente Hegel, desenvolverem algumas teses centrais de suas teorias éticas e ai encontrarem motivos e elementos formadores de suas próprias posiçŏes originais. Depois de ter várias vezes estudado essa doutrina kantiana, já desde os anos de seminário em Tuibingen, tomando-a inclusive, posteriormente, em Bern e Frankfurt, como ponto de partida para o desenvolvimento de projetos próprios, Hegel, ao mesmo tempo que retoma e radicaliza a fundamentação autárquica da moral numa razăo autônoma, vai submeter, na Fenomenologia do Espírito, a teologia moral dos postulados a uma critica não menos implacável, que aquela que Kant fizera à teologia racional como ramo da metafisica especial e à moral teológica, que ele, também, já transformara numa teologia moral. ${ }^{+}$

Antes que Hegel elaborasse a sua teoria da contradiçăo especulativa mediante uma discussăo crítica das antinomias da razão pura e da sua resolução transcendental, a crítica à teoria kantiana dos postulados da razão prática e do sumo bem foi um dos principais condutos que levaram Hegel a questionar a filosofia transcendental em seus princípios teóricos e práticos. Hegel não esconde a virulência que acompanha a radicalidade do seu confronto, aplicando à formulação kantiana da antinomia da razão prática e à sua resoluçăo mediante os postulados, na Dialética Transcendental da Crítica da Razẫo Prática, o que Kant dissera da prova cosmológica da existência de Deus: se esta era para Kant um "ninho de pretensões dialéticas presunçosas (Anmassungen)", a resoluçăo da antinomia da razão prática mediante a teoria do sumo bem e dos postulados, que vão configurar o que Hegel chamará de "visão moral do mundo", são "todo um ninho de contradiçōes desprovidas de pensamento". ${ }^{2}$ Nesta perspectiva, a critica de Hegel à teo-

1 Dusing, Klaus, Die Rezeption der Kantischen Postulatenlehre in den fruhen philosophischen Bntwürten Schelings und Hogcls, In: Hegel-Studien, Beiheft 9, 1973, p. 53-90. Hogel jâ se deftonta com a doutrina dos postulados no Seminário de Tubingen, ao criticar a interpretaçảo teológica dogmática que a Escola de Tubingen fazia dos postulados. Os dois expoentes principais dessa Escola, Storr e Suskind, que foram professores de Holderlin, Hegel e Schelling, partiam da tese da fraqueza da razăo teórica e da sua incapacidade de ter acesso à religiāo revelada e ao conhecimento dos dogmas, e, com a intençlo de fundar praticamente as conteuidos da mensagem evangélica a da teologia racional, os transformavam em postulados da razão prática entendidos como objetos exclusivos de fé. Posteriormente em Bern, e novamente em Frankfurt, Hegel cstuda com afinco a doutrina dos postulados, incorporando-a como elemento principal de um conceito próprio de 'religiáo subjetiva', que ele procurava desenvolver e formular a partir de um conceito racional e puramente moxal da providència divina. Bste implicava, de maneira análoga a como já explicitara Kant na Critica da Faculdado do Juizo, a pressuposiçajo de uma consíderaçăo teleológica da natureza como condição de possibilidade da realização do sumo bem no mundo enquanto fim-Liltimo (Endzweck) de todo agir moral. (jd., p. 68 e ss.).

2 "ein ganzes Nest gedankenloser Widersprúche" G. W. F. Hegel, Phänomenologie des Geistes, Bd. Holfmeister, Hamburg, Meiner, 1952, p. 424. As cttaçб̄es serâo feitas pela abteviaçăo 'Phăn.' indi- 
logia moral do postulados prolonga a critica kantiana à metafisica dogmática e à teologia racional, mostrando que aquela é, no interior do sistema critico, um resto dogmático. A resolução da "visão moral do mundo" nos pressupostos contraditórios da consciência moral, que é obrigada, por fim, a confessar a sua "hipocrisia", vai conduzir à absolutizaçāo da pura certeza moral subjetiva (Gewissen) e, ulteriormente, à sua auto-supressăo, construida por Hegel, na Fenomenologia do Espínto, como passagem à religiăo.

Os postulados da razão prática são suposições teóricas, fundadas praticamente, que enunciam as condições necessárias de possibilidade da realização do sumo bem (das höchste Gut) ${ }^{3}$ pelo agir moral humano. A sua realização, ou mais precisamente, o seu "fomento" ou "promoção" (Befördenung) é um dever derivado da lei moral, enquanto esta não só determina a vontade pura segundo a forma universalizável da máxima que preside ầ ação, mas é, simultaneamente, o fundamento (Grund) que determina a vontade de um ser racional finito, que age segundo fins, a querer a realização do sumo bem como o seu "objeto verdadeiro" e o seu "fim necessário mais alto" (KpV A 207), o seu "fim-último" (Endzweck) (KpV A 233). Se o sumo bem visado inclui em sí a lei moral como sua condição incondicionadà, concebida esta como o "bem supremo" (das oberste Gut), então ele constitui o "bem total e perfeito", o "bem consumado", cuja existência possivel mediante a ação moral não só e o "fim-último" do ser racional finito, mas inclusive "o principio determinante da vontade pura". Todavia, ele não faz parte do âmbito da fundamentaçăo da moral e nem é, por si só, princípio determinante da vontade pura, mas só o é ao incluir a lei moral em si. Ele é "o objeto integral da razăo pura prática" e, simultaneamente, o fim total da "faculdade de apetecer de seres racionais finitos", que, na sua dualidade irredutivel de vontade pura e vontade sensivel, exigem, "mesmo no fuízo de uma razåo imparcial", que o seu objeto integral inclua a expectação legitima de uma felicidade proporcional à virtude, portantc, a realização do conjunto dos fins empiricos compativeis com as máximas morais. (KpV A, 197-199) O sumo bem de um ser racional finito, tem de, portanto, integrar em si os dois elementos, a virtude e a felicidade, e no sentido mais amplo, a moralidade e a natureza, que compôem o bem perfeito, pois carecer da felicidade e ser dela digno, e todavia não participar da mesma, é inconciliável com o conceito de um querer perfeito, cujo poder seria equivalente ao seu querer. (KpV A 199) E na medida em que o sumo bem integra em si, também, a plena realização conjunta dos fins humanos de todos os agentes (a felicidade do gênero humano) na propor-

caçăo da página desta edição, seguida imediatamente, apd́s virgula, da numeração dos parágrafos, introduzida pela traduçäo ingiesa de A. V. Miller (Phenomenology of Spirit, Clatendon Pross, Oxford, 1977), e retomada na traduçä́o brasileira de Paulo Meneses (Fencmenologia do Espirito, I, II, Petrópolis, Vozes, 1992). As traduçóes săo do autor, quando nằo hodver referência expressa à ediçalo brastleita.

3 I. Kant, Kritik der praktischen Vemunft, Bd. Weischedel, Darmstadt, Wissenschaftliche Buchgesellschaft, 1966, v. IV, A 198. As páginas serầo citadas segundo a paginaçăo da $1^{\prime}$ ediçẫo (A). Será parcialmente utilizada a trad. port. de Arthur Morăo, Lisbog, Bd. 70, sem data. Diferentemente de Moräo, traduzirel "das hochste Gut" por "sumo bem", e năo por "soberano bem", nấo só porque Kant também utiliza a expressăo latina "summum', mas tambèm para marcar melhcr a diferença entre o "sumo bem" e a lei moral como "bem supremo", "oberste Gut". 
çáo da realizaçẵo dos seus fins morais, a sua sintese constitui o sumo bem de um mundo possivel, que deve ser plasmado pelo agir moral. ${ }^{4}$

Como a condição principal para a determinação autônoma da vontade, na Analitica da Critica da Razão Prática, é a sua determinaçăo absoluta e imediata pela lei moral, entendida como a forma legisladora universal da máxima, com a exclusâo de todos os princípios práticos materiais, Kant, na Dialética, vai deduzir transcendentalmente a necessidade de reintegrar, numa sintese apriori, mediante a açăo de um ser racional finito, que tem o dever derivado de realizar o sumo bem, as máximas morais e as máximas da felicidade, a liberdade e a natureza, que a Analítica separara por considerá-las "totalmente heterogêneas". (KpV A 202) Visto que as exigèncias da determinação autônoma da vontade năo permitem que disposiçåo de ânimo moral (Gesinnung) e felicidade sejam pensadas analiticamente como "ações totalmente idênticas" - a felicidade como a consciência derivada da posse da virtude, como queria o estóico, nem a virtude como mera consciência da máxima que conduz à virtude, como queria o epicurista - segue-se que a conexão entre as duas é uma conexăo real segundo o princípio de causalidade. (KpV A 200205) E como nem é possivel que a felicidade seja a causa das máximas da virtude, pois estas não săo morais, nem a virtude, causa da felicidade, pois a natureza regida pelas leis causais e o curso do mundo não se regulam pelas intenções morais, a razăo só pode pensar a possibilidade desta conexăo necessária, constitutiva do sumo bem (que a lei moral ordena a vontade humana fomentar), mediante o postulado de um "sumo bem originário" (KpV 226) que garanta esta ligação sintética num mundo inteligivel, mesmo se as ações que procuram realizá-lo tenham de se inscrever no mundo sensivel. A razão prática, que ordena à vontade pura o fomento do sumo bem como seu objeto necessário e total, "ligado indissoluvelmente" à lei moral, e que, contudo, não pode sozinha nem conhecer nem assegurar a possibilidade da sua realizaçăo, defronta-se aqui com a sua antinomia. (KpV, A 199-205)

A sua resoluçäo se dá mediante o postulado de um "sumo bem originário", que, como um "autor inteligivel da natureza" (KpV A 226), não só garante a "perduraçăo' (Fortdauer) do sujeito de um progresso moral ao infinito (postulado da imortalidade da alma), mas nos permite "pensar pelo menos como possível (mas nem por isso conhecer e discernir) uma ligação natural e necessária entre a consciência da moralidade e a expectaçăo de uma felicidade a ela proporcionada como sua consequêência". (KpV, A 214) A imortalidade da alma, a existência de Deus e a liberdade positiva, esta última entendida como autocracia, no sentido da disposiçăo moral (Gesinnung) constante (virtude) de agir para realizar o sumo bem, serăo, então, postuladas pela razão, como condições praticamente necessárias para que seja possivel essa transformação do mundo na perspectiva do sumo bem, exigida pela leí moral. Os postulados săo, portanto, proposições teóricas, porém teorica-

4 "Ora, na medida em que a virtude e a felicidade constituem conjuntamente a posse do sumo bem numa pessoe e em que tambem a felicidade é repartida em proporçäo com a moralidade (como valor da pessoa e seu mérito de ser feliz), formam o sumo bem de um mundo possivel: isto significa, pois, o todo, o bem perfeito, em que, no entanto, a virtude encquanto condiçấ, é sempre o bem supremo [....]." (KpV A 199) 
mente indemonstráveis, cuja necessidade só pode ser fundada praticamente, exigidas pelo dever de fomentar o sumo bem, imposto pelo "fato único da razăo" que é a apoditicidade da lei moral, e que concernem às "condiçð̃es fisicas ou metafisicas" de que a vontade pura de um ser racional finito posisa realizar o seu objeto total e alcançar o seu fim-último. (KpV, 196, 244, 258)

Esta resolução kantiana da antinomia da razão prática através dos seus postulados constituirá a matéria prima do que Hegel chama de "visăo moral do mundo". A sua critica e a destruiçăo dos seus pressupostos teológicos consistirá em mostrar que essa 'Weltanschauung' se constrói sobre a separaçăo e a afirmação unilateral dos opostos, entre os quais a consciência moral (moralisches Bewusstsein) oscila, pondo ora um, ora outro, como essencial, a fim de enconbrir o seu contrário. Esta operação fundamental Hegel denomina Verstellung, ${ }^{5}$ 'deslocamento dissimulador'. Hegel parte de uma análise da contradição fundamental que perpassa a consciência moral, entendida como vontade determinada pelo puro dever, e que se desdobra nos postulados e na sua pretensa função de resolver a antinomia da razăo prática. Em seguida, ele reconstrói, a resolução kantiana da antinomia da razão prática e os postulados da imortalidade e da existência de Deus como figurações dessa consciência moral, que em sua experiência de si será compelida, ao final de um longo percurso por uma série de deslocamentos dissimuladores, a desmentir os seus pressupostos constitutivos, a confessar a sua 'hipocrisia' e a reconhecer a teologia moral como um 'mundo do deslocamento dissimulador'. (Phăn., 444, § 631) A fenomenologia da 'visăo moral do mundo' nada mais é, assim, do que o processo de objetivação e auto-apresentaçăo dessa consciência moral, que faz a experiência da sua contradição desdobrada e projetada nos postulados. Através desse processo em que ela perfaz a experiência completa de si mesma, ela chega então à apreensão conceitual dessa 'visão moral do mundo' como um mundo projetado pelos 'deslocamentos dissimuladores' que articulam os postulados. Inicialmente é somente a reflexăo fenomenológica, o nós, que tem consciência dessa gênese transcendental da 'visâo moral do mundo' constituída pelos postulados, gênese que se tornará, todavia, explícita e temática para a própria consciência moral à medida que ela percorre o périplo da sua auto-

5 Diferentemente da traduçäo brasileira, e tambem da itallana de Negri, que verte Verstellung por 'distcrçá̃o', termo que remete ao 'torquere' latino, reforçado pelo prefixo 'dis', correspondente a um dos sentidos do prefixo alemão 'ver', sugito a traduçăo de Verstellung pot 'deslocamento dissimulador', que me parece mais adequada, 1) porcue o verbo stellen, 'colocar', e o substantivo Stelle, 'local', 'lugar', 'pcsiçăo', remetem ao 'locus' latino, contido analogamente no 'deslocar", que é aliás o sentido primário do alemão verstellen, freqüentemente com o sentido secundárto de 'mudar para o lugar errado', donde, posteriormente, o sentido derivado de 'mudar 0 aspecto ou semblante (do rosto ou da escrita)', e, por fim, o sentido de 'dissimular', e, mais raramente, de 'desfigurar'. (Paul, Hermann, Deutsches Worterbuch, Tublngen, Max Niemeyer, 1897, 5 " ed., 1966, p. 746); 2) porque, como conceito operatótio tundamental da sta critica, Hegel contrapỏe a todo momento verstellen / Verstellung a aufstellen / Aufstellung, invocando o seu radical comum, para jogar com a alternâncla e complementaridade das duas ạ̧ōes, que serão mais adequadamente vertidas pelo 'colocar' ('pór de pé') / 'colocaçăo' e 'deslocar' / 'deslocamento'. A este substantivo se adiciona o adjetivo 'dissimulador', para dar conta do aspecto encobridor e enganador do 'desiocamento'. (PhG, p. 434, \$ 617; pp. 434-444, \$\$ 617-631) A traduçảo do termo por 'distorçẫo' năo faz ver este jogo essencial dos opostos (colocar - deslocar, colocaçăo - deslocamento) separados no interior da antinomia, que é fundamental para a critica que Hegel taz a esta. 
apresentação e da sua experiência. No seu termo ela apreende conceitualmente a oposição entre o que era pensado como em si, o 'santo legislador' posto como transcendente, agora concebido como nulo (nichtig), e o que era experienciado como a mediação imanente da açăo efetivamente real (o si-mesmo), afirmando, ao termo, a identidade desses opostos separados na autoconscięncia moral. (Phän., 443-444, § 631)

Destaco, a seguir, o que me parecem as quatro teses principais desta reconstrução destrutiva que Hegel empreende da teologia moral kantiana:

1. A "visăo moral do mundo" resulta dos desdobramentos da contradiçăo fundamental da consciência moral em várias oposições, cuja resoluçẫo, na forma dos postulados da razăo prática, ela projeta ${ }^{6}$ num além inteligivel, como objeto de uma crença subjetiva racional. Estes operam no registro do puro pensamento (para Hegel mero pensamento representativo, não conceitual) uma mediação transcendente dos opostos, que ela se recusa a reconhecer como contida no próprio agir moral.

2. A consciência moral nessas suas oposiçōes e resoluçōes postuladas "se propele"7 (sich fortwälzt, 432, 437, §§ 611, 621), "rola adiante", por um movimento básico e recorrente de deslocamento e dissimulação (Verstellung), que constitui a sua própria trama e de que ela tem consciência (434, §617), e que se lhe revela ao fim como sua hipocrisia constitutiva. Este 'deslocamento dissimulador' consiste em pôr um extremo da oposiçăo para, imediatamente, e precisamente em relaçăo a esse momento recém posto, passar ao momento oposto. Noutras palavras, a afirmar um momento como sendo em si ou essencial, para em seguida, imediatamente, passar à afirmação do oposto como sendo em si ou essencial. (435, § 617)

3. A consciência moral que percorreu o périplo dos seus deslocamentos dissimuladores, perfaz a experiência de si e ao termo de suas contradiçōes, objetivadas na 'visăo moral do mundo' "colapsa adentro de si mesma". (443, § 631) Neste colapso ela é coagida a reconhecer: a) que o princípio da mediação dos opostos, projetado sucessivamente no conteúdo dos postulados, é imanente ao seu agir moral efetivo, concebido como "realizaçåo efetiva" (Verwirkli-

6 Embora o verbo e substantivo de origem latina, 'projetar' (projizieren) e 'projeçlo' (Projoktion), no sentido fundamental que eles adquirem posteriormente na crítica antropológica de Feuerbach à religiảo e, mais tarde, antes de tudo, na psicanalise de Freud, nāo ocorram literalmente neste contexto, e nào sejam registrados pelo "Indice Geral" (Register) da extiçio Suhrkamp, Hegel utiliza a expressão hinaussetzen ausser sich selbst $(445, \$$ 632) para designar este "transpot-para-fora de sil mesma', como traduziu muito bem P. Menezes, em que a consciẻncia projeta fora de si a sua 'contradiçalo [interna] segundo o conteuido', desdobrando-a entāo numa "contradiçăo segundo a forma', em que se opóem o arquitipo da moralidade perfeita postulada na figfura do santo legisla. dor $e$ a consciència moral imperfetta, que contudo sabe que o puro dever tem validade absoluta para ela. (ibid.) Além disso, a idếla central que presidirá á critica posterior da religiấo, desmitologizada como a auto-alienaçâo da essência humana pela sua objetivaçăo (verobjektivieren) e hipostasiaçăo (hypostasieren) (termos que correm com frequéncla na Bssêncla do Cristiantsmo de Feuerbach) num ser divino, já está presente na tese hegeliana, segundo a qual a "visప̃o moral do mundo" é a "apresentaçáo" o o "desenvolvimento" do conceito da consciência moral, que se toma objeto para si mesmo e se intuf naquela.

7 Proposta da traduçéo de G. Jarczyk e J.P. Labarriète. Phénomenologie de l'Esprit, Paris, Galìmard, 1993, pp. $535,537$. 
chung) do puro dever na açăo; b) que a pretensa separação dos opostos e a dissociaçăo ou "extraposiçăo" (Auseinanderstellung, 444, § 631) da mediação imanente à açăo e da sua projeçăo pensada num além (seja indefinido, seja infinito) é a raiz última desse "mundo do deslocamento dissimulador" (ibid.) que constitui a visão moral do mundo. Hegel pretende com esta tese invalidar os dualismos kantianos entre vontade pura e vontade sensivel, entre liberdade e natureza, puro dever e ação, e superar a diferença , a independência e a heterogeneidade totais (KpV, 202-203) dos elementos do sumo bem, a virtude e a felicidade, bem como a separação estrita entre a concepçăo formal da autonomia (Analitica) e a reunificação sintética desses elementos no "bem total e perfeito" (KpV, A 198), que exige a postulação de um "sumo bem originário" (KpV 226), visto que ele não pode explicar teoricamente a sua unidade intrinseca no seio do próprio agir moral (Dialética).

4. A tese da inevitável hipocrisia da consciência moral: se a consciência moral mantém e leva a sério a separação dos opostos e a "extraposiçăo" da mediação imanente e da sua projeção transcendente como termos irredutiveis ela é hipócrita, pois isso significa recusar a reconhecer af a raiz dos deslocamentos dissimuladores $\theta$ da ordenaçăo teológico-moral do mundo; mas negar a separação e a diferença última dos opostos é, também, negar todo o "mundo do deslocamento" que entretece a visåo moral do mundo, de sorte que negar o próprio percurso pelas oposiçōes, que unicamente dá realidade à consciência moral, e, assim, "desprezar esse deslocamento dissimulador já é a primeira extemação da hipocrisia. (444, $\S 631$, fim)

\section{2 - Análise da contradiçảo da consciência moral e do postulado da hamonia da moralidade e da natureza extema como fim-último (Endzweck) do mundo}

\section{a) O ponto de partida da critica à moral kantiana na arquitetônica da Fenome- nologia do Espirito.}

O ponto de partida da análise da consciência moral, considerado na sua inserçăo sistemática na Fenomenologia do Espíito, é a figura do "espirito certo de si mesmo" (VI, C), em que culmina a fenomenologia do espirito considerado em sua existência no mundo, antes que o capitulo sobre a Religião (VII) considere o espirito no seu si-mesmo absoluto. O espírito, que é, primeiro, eticidade imediata (VI, A), e, depois, espirito que se aliena de si (VI, B), ao final do processo de sua exteriorizaçāo completa refluf inteiramente em sua interioridade simples, mediante a experiência da negatividade absoluta do terror revolucionário (VI, B, c), porque essa negatividade do terror revolucionário contém para ele a coincidência imediata da "vontade universal", considerada nessa "sua última abstraçăo" do puro terror da morte sem sentido, com a autoconsciência singular. ${ }^{8}$ Esta, torna-se, entăo, o

8 "Mas esta negaçlolo [da morte sem sentido, do puro terror do negativo] em sua realidade efetiva nâo é algo estranho; [... I mas a vontade universal, que nessa sua última ahstraçăo nada tem de po. sitivo, e que por isso nada ode retribul pelo sacrificio; - mas precisamente por isso essa vontade universal é imediatamente um só coisa com a autcoonsciência, ou seja, é o puramente positivo, 
puro saber de que a vontade universal em sua identidade com ela e esse mesmo saber constituem a sua essência. (422, § 594) Na experiência da liberdade absoluta do terror se igualiza, assim, a oposição entre vontade universal e vontade singular, entre "o puro querer e aquele que quer", e o espírito alienado encontra-se aí a si mesmo para além dessa oposiçăo (422, § 595): daí resulta que a substância ética, a sua realidade efetiva no mundo, se iguala à sua autoconsciência, de sorte que a interioridade do puro saber e querer do espírito passa a ser a nova efetividade, "espirito certo de si mesmo". 9 A tese da autonomia da razão prática resultante da revoluçāo copernicana no terreno da moral retoma e radicaliza, para Hegel, na interioridade da autoconsciência moral, a experiência da liberdade absoluta da Revolução Francesa.

Nessa certeza moral de si, na qual refluju toda substância ética e objetividade mundanal do espírito, o espírito sabe-se absolutamente livre, pois o puro saber e querer da liberdade passa a ser "a substância, o fim e o único conteúdo" $(424, \S$ 528) da sua figura como consciência moral. Esta sabe que a substância ética, elevada à vontade universal e apropriada pela autoconsciência, é agora idêntica com ela enquanto singular, tanto de maneira imediata, de modo análogo a como a consciência ética sabe e cumpre espontaneamente o seu dever pela sua inserçăo na comunidade ética, quanto, ao mesmo tempo e inseparadamente, de maneira absolutamente mediada, pois essa substância foi purificada pela negatividade absoluta da "morte sem sentido", experimentada na "liberdade absoluta" do terror. A consciência moral como figura do "espírito certo de si mesmo" é, no seu ponto de partida, ao mesmo tempo, puro pensar e querer, e pura realidade efetiva sem as diferenças experimentadas no terror. Enquanto esta autoconsciència, é imediatamente idêntica com a realidade efetiva (a subståncia ética), ela sabe, nesse seu saber e querer puro da liberdade, que o dever é a sua "essência absoluta" (424, § 599) e a sua identidade pessoal mais profunda. Ela está, portanto, na sua determinaçăo absoluta e incondicionada pelo dever, "encerrada em si mesma" na autarquia da sua interioridade moral. Porém, simultaneamente, graças àquela mediação absoluta da realidade efetiva que lhe é igualmente constitutiva, a consciência moral se refere a um ser-outro, a uma natureza externa e interna, pois se o dever é o seu fim essencial, ela tem também outros fins que não se reduzem ao dever. Nessa compreensão da autonomia da razão prática em termos do puro dever e na conseqüente diferença de principio entre vontade pura e sensivel já se delineia para Hegel o que constituirá a contradição da consciência moral.

porque ela é o puramente negativo, e a morte sem sentido, a negatividade năo preenchida do simesmo se inverte, no conceito interior, na positividade absoluta." (Phän., p. 421, § 594)

"Como o reino do espirito efetivamente real passa ao reino da fe e da intelecçáo, assim tambem a iberdade absoluta passa de sua realidade efetiva que a si mesma se destrói para um cutro pais, do espirito autoconsciente, no qual ela vale, nessa inetetividade, como o verdadeiro... e sabe este ser encertado na autoconsciéncia como a essência perfeita e completa. Surgiu a nova figura do espinito moral." (Phän. p. 422, § 595) 


\section{b) Análise da contradiçẳo da consciência moral}

Este ser outro, a natureza, ao qual a consciência moral determinada incondicionadamente pela lei moral contudo se refere, tem para ela uma dupla valência: 1) em face do dever como "único fim e objeto essencial" (424, § 599), que a consciência moral tem de, contudo, realizar no mundo mediante a sua açăo, o seroutro da natureza é, por um lado, "uma realidade efetiva inteiramente desprovida de significaçăo" (ibid.), e como tal, inessencial em relaçảo à essencialidade do dever; mas em face dessa consciência "perfeitamente encerrada em si mesma", cuja vontade é boa tão só pela sua disposição de ânimo (Gesinnung) moral, por outro lado, esse ser-outro é uma existência empírica, inteiramente abandonada $e$ entregue à sua exterioridade própria. Em contraposiçâo a essa interioridade moral do puro querer e da determinação absoluta da vontade pela lei moral, a natureza é uma exterioridade que só se refere a si, plenamente indiferente, dotada de leis próprias e de um curso próprio. "Quanto mais livre se torna a consciência de si, tanto mais livre, também, o objeto negativo de sua consciência." (425, § 599) Hegel enuncia aqui dialeticamente o dualismo kantiano entre liberdade e natureza.

Essa relação de dupla valência entre dever e natureza, constitutiva da consciência moral, é, para Hegel, em sua base, implicitamente contraditória, pois ela é, ao um só tempo, 1) uma relação de plena indiferença reciproca entre dois termos diversos, a independência própria, "em si e por si" da determinação moral da vontade, e a independência própria "em si e por si" da natureza e de suas leis (relaçāo de diversidade); 2) uma relação de oposiçăo não equivalente entre os opostos, em que prevalece "a consciência da essencialidade exclusiva do dever" sobre a "inessencialidade da natureza", que em sua exterioridade dependente deve se subordinar ao dever e ser conformada à lei moral (relaçăo de oposiçăo na dominaçăo) ${ }^{10} \mathrm{~A}$ contradição desta relação da consciência moral com a natureza como seu ser-outro está em que ela é simultaneamente uma relação de diversidade entre termos indiferentes e uma relação de oposição entre desiguais: uma relação de indiferença entre a 'Selbständigkeit' da natureza e a determinação absoluta da vontade pela lei moral, que se traduzirá na diversidade radical (a 'fenda' ou o 'abismo', die Kluft) entre liberdade e natureza, e uma relação de oposição entre o dever que é essencial à consciência moral e a natureza que ine deve ser subordinada, pois esta "só tem realidade efetiva na medida em que é conforme ao dever" (Phăn., 433, § 612), que se traduzirá na necessidade de pressupor uma afinidade entre ambas para que a realizaçåo do sumo bem no mundo seja possivel.

Fenomenologicamente, essa contradiçăo intrinseca à consciência moral, concebida como puro dever em relação à natureza, é caracterizada mediante a oposiçăo fenomenológica entre a autoconsciência moral, entendida como autarquia da determinaçăo absoluta da vontade pela lei moral em face de uma natureza indiferente, dotada de suas leis próprias, e a consciência moral, entendida como prevalência dessa determinação incondicionada da vontade sobre uma natureza, que

10 "Serve de fundamento a essa relaçâo năo só a total indíferença e independência prọ́pria da nature$z a$, e dos fins e atividade morais reciptocamente, mas também, de outra parte, a consciência da exclusiva essencialidade do dever e da completa dependencia e inessencialidade da natureza." (Phăn., p. 425, 5600 , trad. de Paulo Meneses) 
deve ser conformada ao dever pelo agir moral e, em última instância, no fomento do sumo bem, tornada adequada à expectação (Erwartung) legitima de uma felícidade proporcional à virtude. Malgrado a indiferença entre dever e natureza, fundada kantianamente na diferença transcendental entre a determinaçăo inteligivel da vontade e as conexōes causais do mundo fenomenal, a natureza deve contudo, na sua "realidade efetiva inteiramente desprovida de significaçäo" (424, § 599) ser subordinada ao dever. Essa dupla dimensão da relaçâo entre dever e natureza, de certa maneira, corresponde 1) à separaçāo estrita que Kant estabelece, na Analiti$\mathrm{ca}$, entre, a autosuficiência fundacional da razão prática originariamente autolegisladora (o fato da razăo) (KpV, A 55-56), de um lado, e os principios práticos materiais que determinam a vontade sensivel, como se "o esforço por ser virtuoso e a busca racional da felicidade" fossem "duas açōes diversas", "11 por outro, e, 2) à necessidade de integrar, na Dialética, mediante uma sintese apriori, no sumo bem, esses dois componentes radicalmente diferentes, a virtude e a felicidade, considerada esta como retribuição proporcional à virtude. (KpV, A 198, 202-203) Isso que Kant separara na Analítica e na Dialética Hegel vai considerar então conjuntamente, mostrando que o dever de realizar o sumo bem e a postulaçăo das suas condiçōes metafísicas estão essencialmente implicados na moralidade, na medida em que ela, como uma figura do espírito ("a visăo moral do mundo"), resulta do desenvolvimento dos "pressupostos conflitantes" dessa relação implicitamente contraditória entre dever e natureza, concebidos fenomenologicamente como momentos internos do "espirito certo de si mesmo". ${ }^{12}$

c) Critica à concepçẫo moralidade como puro dever: a relação entre disposiçăo de ânimo (Gesinnung) e açăo moral.

A estratégia inicial de Hegel, que determina toda a sua reconstrução critica da moral kantiana como "visão moral do mundo", é a de questionar a maneira como Kant concebe a relaçăo entre a determinaçăo da vontade pela lei moral e a açăo moral que a realiza efetivamente. Para Hegel, o modo como a Analítica demonstra a sua tese central, de que a razão pura só pode ser por si mesma prática se ela determina a vontade independentemente de toda motivação empírica, implica, primeiro, numa separaçăo entre vontade pura e vontade sensivel, entre a determinação absoluta e imediata daquela pela forma universal de lel, o "puro

11 "A conexăo da virtude com a felicidade pode, pois, conceber-se de tal modo que ou o esforço por - \$gr. virtuoso e a busca racional da folicidade não săo duas açũes diversas (verschiedene), mas açóes totalmente idênticas, visto que não é preciso fundar a primeira numa outra mádima diversa da da segunda; ou essa conexảo é estabelecida de modo que a virtude produz a felicidade como algo distinto da consciéncia da virtude, tal como a causa produz um efeito." (KpV A 200) Embora esteja Kant, na primeira trase, criticando a posiçăo epicurista e estoicista, para as quais o esforço virtuoso e a busca da felàidade seriam "açbes totalmente idênticas", se diferenciando apenas por colocarem o seu principio ou na felicidade, ou na virtude, respectivamente, Kant acaba sugerindo, todavia, a contrario sensu, que a fundamentação formal da moralidade exigiria separar a tal ponto esses dois componentes da ação, o correspondente à intençăo moral e o correspondente à realiza. çâo de um fim contido em toda açâo, a ponto de considerá-los implicitamente "chuas açbes diversas". Moråo traduz incorretamente 'verschiedene' por 'diferentes'.

12 "A visilo moral do mundo contém o desenvolvimento dos momentos que estalo contidios nesea relaçăo de pressupostos assim totalmente conflitivos." (Phẵn., 525, § 600) 
dever", e o cumprimento deste dever pela açăo moral, que exige a vontade sensivel na medida em que esta tem de realizar efetivamente essa determinação da vontade inserindo-a no curso do mundo; segundo, que esta separaçăo é tributária da estrutura implicitamente contraditória da consciência moral como relação entre dever e natureza, a qual remete, em última inståncia, ao dualismo kantiano entre razão e sensibilidade e à diferença transcendental entre fenômeno e coisa em si. Esta concepção da moralidade e da razão prática como puro dever faz com que a realização deste pela açāo moral não contenha como tal a realizaçăo dos fins concretos da ação e a consciência que o agente individual tem da sua auto-realização. Disso resulta, aos olhos de Hegel, que Kant não leva suficientemente a sério a relação intrínseca e essencial entre a determinaçăo da vontade pelo dever e a sua realizaçăo efetiva através da ação concreta, donde o conflito entre o "puro dever" e o "dever cumprido" mediante a ação. $(426$, § 602) Esta é a critica básica de Hegel, que presidirá à sua reconstrução crítica da antinomia da razåo prática, da sua resoluçăo e dos postulados á implicados. A contradiçăo básica, que está na base de todas as outras que geram os postulados, é, portanto, a separação entre a consciência moral concebida como puro dever e a realidade efetiva da açăo cumpridora do dever, na medida em que esta implica uma relação intrínseca entre a vontade pura e a vontade sensivel, e uma afinidade efetiva entre liberdade e natureza.

A análise fenomenológica parte da situaçăo conflitiva de que o dever é essencial para a consciência moral, que tem de realizá-lo efetivamente por uma ação que visa conformar a natureza à lei da liberdade, mas que para tanto tem de se inscrever numa natureza regida por leis naturais indiferentes às disposiçōes de ânimo morais da vontade, e que "não se importa" (unbekümmert ist) em the devolver a consciência da unidade entre a sua realidade efetiva $e$ a da natureza, implícita na açăo cumpridora do dever. $(425,601)^{13}$ Por isso que, ao comparar-se com a consciência não-moral, que talvez tenha casualmente levado a bom termo a sua ação, a consciência moral encontre aí razăo para queixar-se de que, sendo "o seu objeto o puro dever", the seja todavia recusada a consciência da realizaçăo efetiva do dever e, nele, da sua própria realizaçăo individual. (ibid.)

A consciência moral, que sabe que o puro dever constitui a sua identidade racional, sabe igualmente que a ação é indispensável para o seu cumprimento, pois é ela que realiza efetivamente a determinação "absoluta e imediata" (KpV A 55) da vontade pela lei moral. Ainda que seja a disposiçäo de ânimo (Gesinnung) de respeito à lei o que qualifica a moralidade da açāo em sua raiz (ela é apenas face subjetiva da determinaçăo objetiva e apriori da vontade pela lei), a consciência moral não pode separar dessa disposição 1) a sua realização efetiva, isto é, a da determinação da vontade mediante a ação e 2) a fruiçăo que o agente singular tem da sua auto-realizaçăo ao executar a açăo moral. Isso porque o puro dever, ainda

13 \% [... toda conexảo prática das causas e efeitos no mundo, como resultado da determinaçăo / da vontade, năo se regula pelas disposiçóes morais da vontade, mas pelo conhecimentos das leis natura's e pelo poder fisico de as utflizar para cs seus objetivos; por conseguinte, năo pode esperatse no mundo, mediante a mais precisa observaça das leis morais, nenhuma conexalo, necessária $e$ suficiente para o sumo bem, da felicidade com a virtude." (KpV, A 204-205, trad. A. Morão, modifcada na traduçấo de das höchste Gut por "sumo bem", ao invés de "soberano bem". 
que não tenha nenhum fim por fundamento, é concebido como o "fim absoluto" da consciência moral, que, por ser fim, implica necessariamente a ação de um agente singular que o efetive e, também, "a convicçåo individual ciente de si" de que esta determinação da vontade constitui precisamente o dever. (426, § 602) Por conseguinte, não só a conviç̧ão ciente de sí dessa autoconsciência singular, na sua açăo efetivadora do dever, constitul para Hegel "um momento absoluto da moralidade" (ibid.), tão essencial quanto a consciência do puro dever, mas a própria fruiçāo que a consciência moral tem de si, ao intuir a sua auto-realizaçăo no fim objetivado, está implicada na determinação da vontade, precisamente porque 0 puro dever como fim exige a sua realizaçăo efetiva pela ação, e não pode permanecer mera interioridade em oposiçăo à açăo. ${ }^{14}$

"Esse momento no fim tornado objetivo, no dever cumprido, é a consciência singular que se intui como efetivamente realizada, ou seja, é a fruiçăo, que reside por isso no conceito de moralidade, de certo năo imediatamente no conceito de moralidade como disposição de ânimo [como determinaçăo da vontade], mas no conceito da sua realização efetiva. Por esse intermédio a fruiçăo reside também na moralidade como disposiçâo de ânimo, pois esta tende não a permanecer disposição de ânimo em oposição ao agir, mas a agir, ou a se realizar efetivamente". (426, $\S 602)$

Esta transformação, de corte aristotélico, do "puro dever" e da Gesinnung kantianos num "fim absoluto" (426, § 602), cuja realização pela ação Hegel concebe como sua "exteriorizaçăo" (Entäusserung) na realidade objetiva, tornam para Hegel a determinaçăo absoluta da vontade pela lei moral intrinsecamente uma açāo, que é ciente da convicção individual que a rege enquanto cumprimento deste dever, e que tem, também, na transformação da natureza mediante execução do fim concreto (correspondente ao dever determinado), a fruição de si mesma, contida na consciência da sua unidade com a natureza interna e externa. A unidade da liberdade moral e da natureza (interna e externa), que para Kant só é possivel sintética e derivadamente mediante o postulado de um 'sumo bem originário', entendido como fundamento ontológico da possibilidade da realizaçăo do sumo bem no mundo pelo agir humano, já está contida para Hegel na própria raiz deste agir, que não precisa saltar a 'fenda' ou 'abismo' (Kluft) entre o reino da liberdade e o reino da natureza mediante aquele postulado. Portanto, 1) a ação moral, 2) a convicçăo individual ciente de si nela implícita e 3) a consciência moral singular que frui a sua auto-realização, implicada na execuçăo do fim no mundo objetivo, săo momentos inseparáveis da disposiçăo de ânimo moral e diretamente implicados nela, pois o sentido desta năo é, como diz Hegel, "permanecer disposição de ânimo em oposição ao agir, mas agir, realizar-se efetivamente". (ibid.)

Assim, agora, o puro dever, em sua unidade inseparável com a ação moral que o executa enquanto ele é fim absoluto e, igualmente, com a natureza interna (implicada na auto-realização do agente) e externa (tornada conforme ao dever pela objetivaçăo do fim nela) é determinado ulteriormente como "fim total" ("o fim

14 "O fim, enunciado como puro dever, implica essencialmente nele o fato de conter esta autcconsciência singular; a conviçăo individual e o saber a seu respeito constituem um momento absoluto da moralidade." (Phầ., 426, § 602) 
como o todo") $\cdot^{15}$ Este fim total já contém a realidade efetiva da harmonia entre ambos, mas ela não é ainda para a consciência moral, pois para ela é igualmente essencial a experiência da oposiçăo entre o dever e a natureza, entre a virtude e a felicidade, de sorte que ela vai somente pensar essa harmonia como necessariamente devendo ser, sem que ela seja efetiva, isto é, ela vai postulá-la. Esta reformulação do dever como fim total conduz a uma ampliação do conceito de ação moral, que permitirá a Hegel refazer a gênese do objeto dos postulados. A gênese vaf mostrar que esse objeto já está implicitamente implicado na ação, na medida em que esta contém a "realizaçăo efetiva" (Verwirklichung) do puro dever ("a açăo puramente moral"), a da singularidade agente mediante a objetivação do fim, e a da unidade da natureza com este. Daí, também, igualmente, uma ampliação do conceito de felicidade, para Kant um conceito empirico, irredutivelmente oposto ao de lei moral, pois ela é representada como "o estado no mundo de um ser racional, para o qual, na totalidade da sua existência, tudo ocorre segundo o seu desejo e a sua vontade [...]". (KpV A 224) Para Hegel, em contrapartida, a felicidade não é algo puramente empirico, nem primariamente um estado, mas a fruição da auto-realizaçăo singular do agente, implícita no cumprimento do dever mediante a açăo moral, que objetiva na natureza esse dever concebido como "fim total".

Mediante essa concepçăo teleológica do puro dever como "fim absoluto" e, considerado no conjunto das implicaçōes da açăo moral que o realiza, como "fim total", Hegel reformula criticamente a teoria kantiana da autonomia prática como sendo o cerne da consciência moral, e estabelece a base para a sua crítica genética aos postulados da razão prática enquanto pressupostos teológico-motais da realização dessa consciência. A crítica visa 1) reintegrar no interior da ação moral - que a Analitica e a Dialética haviam separado, a determinaçăo incondicionada da vontade pela lei (o puro dever) e a promoçăo do objeto total e fim-último, da vontade, o sumo bem, 2) subverter o dualismo kantiano entre o puro e empírico, eliminar a heterogeneidade total (KpV A 202) entre o princípios formais e o principios materiais da ação, pressupostos pela fundamentação da moral, 3) superar a conseqüente cisāo da ação em dois componentes e dimensões irredutiveis, e 4) restabelecer uma afinidade efetivamente real entre liberdade e natureza, que Kant só pode pensar mediante os postulados da teologia moral. Com efeito, é essa heterogeneidade total e aquele dualismo que obrigarăo Kant a reunir posteriormente, na Dialética, esses elementos radicalmente heterogêneos, mediante a sua sintese apriori no conceito prático de sumo bem. A realização deste no mundo, por sua vez, exige a pressuposição de um fundamento metafisico que restabeleça a afinidade entre os elementos da açăo moral, que a Analitica tinha separado. A "visão moral do mundo", caracterizada nos termos da teologia moral dos postulados práticos, será para Hegel o desdobramento desta inconsequêência fundamental de

15 "O fim expresso como o todo com a conscléncia de seus momentos consiste, portanto, em que o devet cumprido seja tanto açlo puramente moral, quanto individualidade realizada, e que a natureza, como o lado da singularidade em contraste com o fim abstrato, seja uma-cotsa com o fim." (Phä̀n., 426, \$ 602) 
Kant, "que é unir o que um instante atrás tinha sido declarado como autônomo (selbständig); portanto, como não-univel". ${ }^{16}$

A primeira conclusăo dessa análise é que a experiência inicial da desarmonia entre moralidade e natureza e đa inserção da ação moral numa natureza regida por leis próprias e indiferente aos fins morais, ê tăo necessária quanto a experiência da sua harmonia implicita, já contida "no conceito da realização efetiva da disposiçăo de ânimo" enquanto ele implica os três momentos do dever concebido como "fim total": a ação exigida pela Gesinnung, a convicçăo individual e a felicidade como fruiçăo da autorealizaçăo da consciência singular na ação, que já estabelece uma mediaçāo entre liberdade e natureza. (426, § 602) A harmonia entre moralidade e natureza, virtude e felicidade, que para Kant só pode ser pensada como realizada no sumo bem, mas não conhecida, e que exige o postulado da existência de uma causa originária que contenha o fundamento da possibilidade da conexão entre aqueles opostos (sendo, portanto, somente objeto de uma suposiçāo (Annahme) teórica, indiretamente exigida pela lei moral), é explicada, agora, por Hegel, como derivada da harmonia contida na própria experiência da ação moral concebida como realizaçäo do fim total. A necessidade dessa harmonia para Hegel "reside no conceito da própria moralidade, cujo verdadeiro conteúdo é a unidade da consciência pura e da consciência singular". (426-427, § 602)

A harmonia entre moralidade e natureza, virtude e felicidade, resulta para Kant da necessidade prática de pensar a sintese apriori prática de ambos no sumo bem, cuja realização no mundo deve ser possível, sob pena de a lei moral "ser fantástica" e "falsa em si". (KpV A 205) Essa necessidade de pensamento, para Kant uma 'carência' (Bedürfnis) da própria razão pura prática, fundada no dever (KpV A 257), é interpretada por Hegel como um "exigir" (Fordern) que exprime somente uma necessidade do ser, uma necessidade, portanto, exterior, e não do conceito enquanto conceito. ${ }^{17}$ Esta necessidade do postulado, que só pode ser pensada, significa para Hegel que ela é somente uma necessidade na ordem do ser e que ela ainda nāo se tornou objeto real-efetivo da experiência da consciência moral. Esta 'exigência' da harmonia transferida pela consciência moral para o sumo bem, corresponde, em Kant, ao caráter apenas 'subjetivo' (no sentido transcendental) da necessidade moral de pressupor a possibilidade prática do sumo bem, pois, enquanto 'carência' da razão, ela não é uma necessidade objetiva

16 "Bm todo sistema dualista, mas particularmente no kantismo, seu defeito básico se dá a conhecer por meio da inconsequêtncia, que é unir o que um instante atrás tinha sido declarado como autónomo, como náo-univel. Como há um instante o unido fơ dectarado set o verdadeiro, de repente se declara ser antes verdadeiro que $\infty 6$ dois momentos - em cuja uniajo, como em sua verdade, thes foi negado o subsistir-por-si - só assim, como momentos separados, têm verdade e realidade efetiva." G. W. F. Hegel, Enzyklopeldie der philosophischen Wissenschaften im Grundrisse (1830), Wetke in zwanzig Bände, v. 8-10, eds. B. Moldenhauer e K. M. Michel, Frankfurt, Suhrkamp, 1976. Die Wissenschaft der Logik, v. 8, § $€ 0$ Anotação. Trad. brasileira de Paulo Meneses, São Paulo, Bd. Loyola, 1995, v. I, A Caência de Lógica, p. 134.

17 "A harmonfa da moralidade e da natureza, - ou, enquanto a natureza só é levada em consideraçăo na medida em que a consciência experimenta a sua unidade com ela, - a harmonia da moralidade e da felicidade é pensada como necessariamente sendo, ou ela é postulada. Pois exigit significa que algo seja pensado [como] sendo, que ainda năo é teal-efetivo; uma necessidade năo do conceito enquanto conceito, mas do ser:" (Phăn., 426, § 602) 
como o próprio dever. (KpV A 226) Por isso Hegel mui justamente insiste em que a harmonia exigida não é uma mera aspiração da consciência moral individual ou uma simples representação de um fim cuja consecução é incerta. Ela pertence, diz Hegel, ao próprio conceito de moralidade, embora, e este é o ponto decisivo, ela ainda não seja reconhecida pela consciência moral como necessidade do conceito enquanto conceito. Pertence, assim, ao conceito de moralidade que esta unidade e aquela harmonia já sejam para ele, conceito, uma realidade efetiva $(427, \S 602)$, embora ainda não para a própria consciência moral: esta não sabe imediatamente que a harmonia já está implicitamente presente na ação moral, e, por isso, val projetar a harmonia da virtude e da felicidade e a unidade da consciência (vontade) pura e da consciência (vontade) singular fora de si, num além inteligivel, mediante um postular, que é somente um exigir. $(434$, § 616) Esta "exigência racional" de uma harmonia entre moralidade e natureza, virtude e felicidade, que resulta para Kant de uma "deduçăo transcendental do conceito de sumo bem" a partir da lei moral (KpV A 203) e de uma reflexão transcendental sobre as condiçōes de possibilidade da experiência moral plena de um ser finito (a realizaçã̃o assintótica do objeto total da vontade no sumo bem consumado), torna-se para Hegel um elemento constitutivo imanente da própria consciència moral, já contido na ação moral, enquanto esta realiza efetivamente o puro dever $e$ a autoconsciêncía singular e já contém uma unidade de liberdade e natureza.

Nós, a reflexão fenomenológica, a instância subjetiva do conceito no interior da experiência, sabe, "vê", por um lado, que a própria consciência moral engendra conscientemente esse seu objeto necessário e total, o sumo bem, como unidade do puro dever e da fruiçăo da consciência singular, realizada na açăo moral, e, igualmente, que ela está ciente de si como princípio ativo (als das tätige), que o engendra; mas, por outro, ela vê, também, que a consciência moral năo se aproprou ainda dessa unidade imanente na açăo moral, e que ela a põe como um objeto além, fora de si, que é, porém, (para a reflexão fenomenológica) "sendo-emsi-e-por-si enquanto posto por ela", "em função dela e por ela". (434, § 616)

\section{3- Deslocamentos dissimuladores do 'primeiro' postulado}

Nesta altura Hegel introduz o conceito de 'distorção' ou melhor, 'deslocamento dissimulador' (Verstellung), uma espécie de operador de má-fé da consciência moral, mediante o qual ela desloca e encobre recorrentemente a sua contradiçăo fundamental, que se desdobra em várias oposiçర̄es, entre cujos extremos ela oscila, e cuja resoluçăo ela projeta no mundo inteligivel. No deslocamento dissimulador a consciência moral passa imediatamente de um momento, que ela recém colocou (aufgestellt hat) e fixou como essencial, ao momento oposto, que, por sua vez, recém colocado como essencial, é novamente deslocado e dissimulado (verstellt), precisamente em vista do oposto. Assim, ela confessa que não leva a sério nenhum deles. (434-435, § 617) A consciência, apesar de sucumbir a essa oscilaçâo entre os opostos, está, contudo, consciente desse deslocamento dissimulador da sua contradiçăo fundamental, pois ela năo só fixa um momento da oposição para passar em seguida ao oposto, mas ela opera conscientemente esta passagem ao oposto em relação precisamente a ele, para marcar que ela o afirma 
no mesmo instante em que o nega no seu oposto, e em relação áquela afirmação anterior. Com isso a consciência moral mostra que ela nāo leva a sério nenhum dos momentos opostos entre os quais oscila. A visåo moral do mundo vai resultar do desenvolvimento da consciência através desses deslocamentos dissimuladores, que desencadeiam um "movimento estonteante e impostor" (schwindeinden Bewegung ${ }^{19}$ ) que arrasta a consciência moral, e cuja experiência será o principal objeto da análise fenomenológica. $(435, \S 617)$

Independentemente da pressuposiçăo inicial $(425, \S$ 601) de que haja uma consciência moral efetiva, a postulaçăo de uma harmonia entre moralidade e natureza, que só é em si, significa que ela ainda não está presente para a consciência moral efetiva. $O$ que existe presentemente para a consciência, em face desta harmonia postulada, é a desarmonia da sua (suposta) moralidade com a natureza, que è colocada como estando em contradiçăo com a consciência moral. Como, porém, é só no agir moral que se realiza efetivamente a moralidade da consciência, pois este agir, concebido como "realização efetiva do fim moral interior", é ao mesmo tempo "a produçăo de uma realidade efetiva determinada pelo fim", portanto, também, a produção "da harmonia do fim moral e da realidade efetiva", este agir moral desloca e dissimula imediatamente (1) o que o postulado colocara, inicialmente, apenas como harmonia transcendente. (435, § 618) Com isso, a "consumação da açăo" moral, que é, também a realização efetiva da consciência singular, já é para a consciência moral tanto a presença dessa unidade da realidade efetiva e do fim quanto a fruiçăo dessa unidade. A açăo moral consumada, portanto, já é a realização efetiva da harmonia para a consciência. ${ }^{19}$

A açăo moral, que, inicialmente, a partir da sua desarmonia, colocava a harmonia como só devendo existir num além inteligivel, objeto de postulação, desmente o postulado e diz, por si mesma, que năo o leva a sério, "porque o sentido do agir consiste [agora], antes, em fazer aceder à presença o que não deveria estar na presença" [a saber, a harmonia]. (ibid.) Convém lembrar, aqui, que Hegel denomina de primeiro postulado (o da harmonia da moralidade e da natureza externa) o que corresponde propriamente àquilo que, para Kant, é a resolução da antinomia da razão prática, isto é, a conexão necessária e sintética apriori (cujo fundamento último é o postulado do "sumo bem originário"), mediante a açăo moral que fomenta o sumo bem, entre o "incondicionado" da lei moral (o bem supremo) e a expectaçāo legitima da felicidade, que é a "consequência moralmente condicionada" daquela. (KpV A, 205, 214) Mas agora a situaçäo se inverte por um novo deslocamento dissimulador (2), pois se agora só se leva a sério o próprio agir, é em vista da harmonia já efetivamente contida na consumação da ação moral que ela é deslocada para um além, como inefetiva, precisamente para que ela possa vir a ser efetivada pela ação. É preciso postulá-la como devendo ser fomentada, a fim de dissimular e deslocar a sua presença efetiva na ação moral consumada, pois se a

18 Hegel explora aqui o duplo sentido do verbo schwindeln, que tanto significa ter vertigens, cair em delirio, como lograr, trapacear, fraudar.

19 "(...) e porque na açăo consumada a conscichncia se realiza efetivamente como esta consciencia singular, cu intui o ser-ai lenquanto] retomado nela, e nisso consiste a fruiçăo, assim, na realídade éfetiva do fin moral está também contida simultaneamente aquela forma de realidade efetiva que se denomina fruiçăo e felicidade." Phän., 435, $\$ 618$. 
harmonia já năo fosse efetiva em si, năo poderia vir a sê-lo pela açăo. ${ }^{20} \mathrm{Se}$ inicialmente era a desarmonia entre a consciência moral e a natureza o que exigia o postulado de uma harmonia em sí, é agora a sua presença imanente na própria ação moral plenamente efetivada que vai deslocar o sumo bem postulado para a inefetividade recorrente do dever-ser. O postulado, que era antes a condição da harmonia, é transmudado em algo condicionado pela harmonia presente na própria açăo moral, e a sua funçăo passa a ser, agora, meramente, a de recordar no seu dever-ser impotente a presença efetiva dessa harmonia para a consciência moral.

Mas a essa seriedade da ação moral consumada, que contém nela a harmonia, seguirá novo deslocamento (3), o da própria harmonia presente na ação moral, uma vez que esta é sempre e somente açāo de uma consciência singular. Perante o sumo bem, como "fim universal que tudo abrange (der alles umfassender Zweck) e que tem o "mundo inteiro" por lugar da sua realizaçăo, a açăo moral é somente singular e a sua obra meramente contingente (pois ela é uma harmonia, não a harmonia anteriormente referida, p. $435, \S 618$ ), de sorte que o "fim-último da razāo" não só ultrapassa o conteúdo desta ação, mas todo agir moral efetivo. (436, § 619) Em contraste com um fim tão elevado, que "se coloca além e acima de todo agir efetivo", a consciência moral se apercebe, entåo, da 'inanidade' (Nichtigkeit) do seu agir, e não o leva mais a sério na sua capacidade de 'fomentar' (fördern) e 'produzir' (hervorbringen) 'o melhor universal' (das allgemeine Beste), deslocando e dissimulando a afirmação (a colocação) imediatamente anterior, que dizia ser o agir moral que efetivava a harmonia postulada. Conclusão desse deslocamento: "Porque se deve executar o melhor universal, nada de bom se faz". (436, § 619)

Mas, uma vez colocada essa inanidade do agir efetivo singular em sua contraposição à realidade exclusiva do sumo bem como fim-último do mundo, ela será novamente deslocada e dissimulada pela ação moral (4): na medida em que esta tem o dever por seu 'fim total único', 'absoluto', ao cumpri-lo ela visa, malgrado o seu conteúdo limitado, a realização plena, a consumaçāo (Vollbringung) desse dever, que é fim total, na realidade efetiva. Esta consumação enquanto tal tem por fim, agora, a própria realidade efetiva, pois trata-se de transformar a natureza e o curso do mundo na expressăo consumada da lei da liberdade. Essa 'consonância' (Zusammenstimmung (KpV A262) plena entre leis da natureza e leis morais numa 'natureza suprasensivel', isto é, inteiramente 'submetida à autonomia da razåo pura prática', que para Kant só é possivel num progresso ao infinito, mediante a hípótese de uma razão pura dotada de um poder físico adequado à sua vontade $\mathrm{e}$ de uma "natura archetypa" (KpV A 74-75), resulta para Hegel de uma transformaçăo da realidade efetiva da natureza pela lei da liberdade. Esta transformação exprime uma mediação ontológica, para além do dualismo kantiano, entre natureza supra-sensivel e natureza sensivel. Mas, visto que o dever só tem sentido no conflito com uma natureza dotada de leis próprias e irredutiveis, essa consumação da moralidade plenamente realizada na realidade efetiva da natureza (uma natureza plenamente reformada pela liberdade) terminaria por dispensar o agir pelo dever, engendrando um novo deslocamento.

20 "B por ser a harmonia postulada em vista do agir - o que deve se tornar real-efetivo pelo agit, tem de sê-lo assim em si, pois do contrário a realidade efetiva nảo seria passival -, então a conexăo do agir e do postulado está constituida de sorte que por causa do agir, isto é, da barmonila efetiva do fim e da realidade efetiva, esta harmonia é posta como náo efotiva, como além." Phän., 436, \$618 
Com efeito, se o sumo bem no sentido kantiano do "bem consumado" "aquele todo que năo constitui parte alguma de um todo ainda maior da mesma espécie" ("perfectissimum") porque ele inclui a lei moral como condiçăo incondicionada e bern supremo (originarium) (KpV A 197-198), - for plenamente efetivado pela açăo moral, quer dizer, se ele se consuma na realidade efetiva, tornando a natureza expressão da própria lei da liberdade, a consciência moral deixar de levar a sério a moralidade enquanto dever, pois a açåo moral necessita confrontar-se com uma natureza que the é irredutivel. "Se, porém, a natureza é conforme à lel moral, essa seria certamente ferida pelo agir, pelo suprimir do ente." $(437, \S 620) 0$ agir pelo dever e a consciência moral ativa, que nega a natureza externa dada, perdem, aqui, o sentido e se tornam supérfluos, pois eles só tem sentido na sua oposição à natureza e ao curso do mundo, isto é, enquanto têm de suprimir o negativo (a natureza dada) que a lei moral pressupõe. Assim, o agir moral não pode levar a sério o que ele implica, de sorte que a própria consumação do dever na realidade efetiva será novamente deslocada e dissimulada.

Com isso, o postulado que exige a harmonia entre a lei da liberdade e a lei da natureza como devendo ser ainda realizada na ação moral se condensa, ao final desta primeira etapa, numa proposiçăo paradoxal: "porque o agir moral é o fim absoluto, o fim absoluto é que não se dê de modo algum o agir moral", (437, § 620 trad. P. Meneses) Para a reflexāo fenomenológica fica claro que a consciência moral năo levava a sério nenhum dos opostos desses seus deslocamentos, através dos quais ela se "propelia" (fortwältzte), e a própria consciência moral faz a experiência de que ela nåo leva a sério o agir moral, "senão que o mais desejável, o absoluto, está em que o sumo bem tivesse sido levado a termo (ausgeführt), e o agir moral fosse supérfluo". (437, § 621)

Ao termo desta experiência a consciência se convence de que ela năo pode levar a sério nenhum dos três momentos implicados no cumprimento do dever, nem o postulado da harmonia, nem o próprio agir moral, nem a consumação da moralidade na realidade efetiva, pois ela ainda não tomou consciência de que é 0 próprio agir moral que integra e medeia esses momentos.

\section{4-O postulado da harmonia da moralidade e da natureza intema como fim-último da autoconsciência enquanto tal}

Este resultado paradoxal, o de que a consumaçăo do sumo bem num mundo plenamente ético impede a consciência moral de levar a sério a exigência do dever e torna desejável que o próprio agir moral seja supérfluo, será necessariamente objeto de um novo deslocamento, que impele adiante ("propele") a consciência moral na experiência do seu movimento contraditório. (437, § 622) Como, de um lado, é condiçăo da moralidade que o sumo bem como fim-último do mundo não tenha sido levado a termo, pois para que a consciência moral seja ativa e para si, é preciso que ela se defronte com uma natureza já dada, contraposta a ela $e \mathrm{em}$ đỉssonância com a sua autonomia; mas como, de outro, a experiência final do primeiro postulado (embora objeto de novo deslocamento) continha a exigência da realização cabal ("consumação") da moralidade na natureza, a consciência moral toma novamente a se confrontar com uma natureza, só que ela é, agora, a sua 
natureza interna, a vontade sensivel com seus desejos e impulsos. A interiorizaçăo da oposiçăo marca, para Hegel, a passagem ao segundo postulado. ${ }^{21}$

Um novo deslocamento, que preside a essa passagem, se impōe agora à consciência, o primeiro de uma nova série de quatro: o deslocamento dessa própria supressão e superação (Aufhebung) do agir moral. Duas razōes o motivam: 1) para que haja efetivamente consciência moral, é preciso não só uma sintese em si entre moralidade e a natureza, mas, também, uma síntese para si, de modo que a harmonia postulada possa existir como "fim-último da autoconsciência enquanto tal" $(429, \S 504) ; 2)$ consciência moral enquanto singular e contingente tem a sua própria natureza interna, a faculdade de apetecer inferior com seus impulsos e inclinaçōes, dotados de fins próprios opostos ao puro querer. (427, § 603)

O novo ponto de partida é a simultânea oposiçăo e unidade entre razão e sensibilidade, entre puro dever e vontade sensível. O querer e o pensar puros da razão prática e os impulsos da sensibilidade constituem uma só consciência: mas para ela, enquanto consciência singular agente, o principal é a oposição entre a vontade pura e a vontade sensivel, ao passo que para ela e nela, enquanto razão, enquanto puro pensar e querer do dever, o essencial é a unidade dos opostos e a dissolução da oposição por uma mediaçăo que contenha esta oposiçẳo ciente de si, em que consiste a moralidade efetiva. $(427, \S 603)$

1. Inicialmente a sensibilidade aparece à consciência moral como o seu outro e o negativo, perante $o$ qual ela 'coloca' a razăo como independente das inclinações e dos impulsos e como o seu fim puro, que deve eliminar os fins da sensibilidade. Mas esta supressão da sensibilidade, apenas afirmada, é em seguida deslocada pela consciência moral, que interpōe, como termo-médio (Mitte) entre o puro dever (razăo) e a sua realidade efetiva, precisamente os impulsos, que supostamente deviam eliminados, mas não podem sê-lo, pois eles nada mais săo do que a própria vontade sensivel consciente de sí, que é instrumento e canal de efetivaçăo do fim moral. A supressâo da sensibilidade, recém colocada pela exigência da independência da razão, é portanto deslocada, e o resultado deste deslocamento é que os impulsos năo devem ser 'reprimidos' (438, § 622), mas serem tornados conformes à razão, já que o agir moral nada mais é do que a auto-efetivação da consciência moral mediante a força dos impulsos: 0 agir moral é "a consciência que se dá a figura de um impulso". (ibid.) Mas se săo os impulsos e as inclinações os canais de realização do agir moral, é porque também está nele imediatamente presente a harmonia da moralidade e da sensibilidade, da vontade pura e da vontade sensivel.

2. Mas esta harmonia colocada pelo agir moral é em seguida novamente deslocada, pois seria uma ingenuidade da consciência moral acteditar que a disposiçăo de ânimo moral seja "a mola propulsora dos impulsos (die Triebfeder der Trie-

21 "A partir desse resultado a consciéncia moral tem de propelir-se ulteriormente no seu movimento contraditório e necessariamente deslocar de novo o suprimir do agir moral. A moralidade é o emsi; e para que èa tenha luģar, o fim-último do mundo năo ser levado a tetmo, mas a ccnscténcta moral deve ser para-si e encontraz uma natureza que the seja contraposta (entgegengesetzte). Mas a ocnsciencia motal tem de ser estar nela mesma cabalmente realizada. Isso conduz aos segundo postulado, ao da harmonia de si (mesma) e da natureza que está imediatamente nela, a sensibilidade." (438, \$ 622) 
be) e que ela determinasse o ângulo de inclinação [correto] das inclinaçōes". Mas como o impulso não é "somente esta figura vazia que pudesse ter em si mesmo uma outra mola (Feder) que aquela que ele mesmo é, e que pudesse ser impelido por ela", mas tem a sua natureza e as suas molas impulsoras próprias, seria a própria consciência moral quem se conformaria aos impulsos, ao invés de estes serem conformados àquela. $(438, \S 622)$

Essa harmonia imediata, que seria ingênuo a consciência moral levar a sério, deve, portanto, ser novamente postulada e deslocada para o sumo bem além desta consciência, cuja realizaçăo é, para Kant, 'o objeto necessário' da consciência moral. Não se trata, porém, agora, de uma harmonia somente sendo em-si entre a moralidade e a natureza externa, a ser instaurada fora desta como fim-último do mundo, mas de uma harmonia que a própria consciência moral agente deve realizar para si, como sendo a sua própria, e que constitui "o fim-último da autoconsciência como tal".

3. Mas a consumaçăo desta harmonia da autoconsciência moral e da sua natureza interna num além longínquo, em que a luta necessária entre razão e sensibilidade seria apaziguada, deve ser continua e indefinidamente protelada, pois se a perfeição moral se realizasse e a vontade sensivel fosse inteiramente conforme à razāo, a consciência moral renunciaria à sua autonomia, pois ela só existe na luta e na oposiçăo. Por isso, essa perfeição moral acabada, representada na harmonia postulada de uma sensibilidade plenamente conforme à razăo, deve ser novamente deslocada e dissimulada, porque nesta perfeiçăo a consciência moral se abandonaria enquanto ativa e efetiva, assim como, em contrapartida, a harmonia consumada desaparece na consciência moral efetiva que tem de agir e negar a natureza para realizar o dever. $(428, \S 603$ ) Mas para que seja possivel um progresso moral indefinido de uma consciência sempre em luta com uma natureza interna adversa Kant val introduzir o postulado da imortalidade da alma, entendido como a "inflnitude da sua perduração', ${ }^{22}$ que para Hegel significa um novo deslocamento: como a consciência moral não pode levar a sério a consumação da perfeiçăo moral, projetada no sumo bem, ela a desloca a "uma lonjura nebulosa, onde nada mais se pode distinguir nem conceber com exatidão". (438, § 622)

Mas se só existe moralidade na forma de uma consciência ativa que nega a sua natureza interna e enquanto consciência do puro dever como fim absoluto em oposiçâo a todos os outros fins (ibid.), então a perfeição só pode ser postulada como "tarefa absoluta". (428, § 603) Esta aproximação indefinida à santidade, representada analogamente à aproximação sem fim da linha curva à reta, exigida por uma consciência moral ativa, que "só num progresso indo até o infinito pọde chegar ả plena conformidade com a lei moral" (KpV A 220), é o que torna necessário introduzir o postulado da imortalidade da alma, pois sem ele o dever (ordenado pela lei moral) de promover o sumo bem como objeto da vontade pura seria impossivel, a própria leí moral seria 'fantástica' (KpV A 205) e a sua santidade 'desonrada' (abgewürdigt, KpV A 221). Esta ficaria, como diz Kant, entregue à medida da nossa imperfeição e "adeçuada à nossa comodidade", ou então daria lugar a expectativas teosóficas de uma aquisição da santidade na finitude, "exor-

22 "Unendlichkeit seiner [des Geschơples] Fortdauer', KpV, A 220-223. 
bitando a sua missão". (KpV A 221) Para Hegel, todavia, esta conformidade plena à lei moral na forma do "progresso ao infinito" (Progressus ins Unendliche, id. A 222) do agente moral, esta "aproximação" (Annäherung) infinita pensada como consumaçăo, é uma representaçăo contraditória, desprovida de conceito, pois ela significa, simultaneamente, uma tarefa que permanece absolutamente tarefa, portanto, em princípio, irrealizável, uma aproximação 'ao infinito', mas cujo conteúdo deve ser simultaneamente pensado, no postulado, como necessariamente sendo, como conteúdo que não permanece mera tarefa, mas visa a sua efetivação. $(428, \S$ 603)

4. A resolução kantiana dessa contradição de uma "tarefa absoluta", que deve permanecer tarefa, para que a consciência moral efetiva seja possivel como autonomia e luta, e que, contudo, deve poder ser plenamente cumprida (erfullt) $(429$, § 603), para que o agir da consciência moral visando alcançá-la tenha sentíio, consistirá, aos olhos de Hegel, na instauraçăo do deslocamento dissimulador como procedimento recorrente da consciência moral, que projeta a perfeiçăo sempre mais adiante à medida que age para atingi-la. Pois se ela se apercebesse claramente dessa contradição de um 'progresso ao infinito' (Kant) como 'tarefa absoluta' (Hegel), e não a dissimulasse reiteradamente pela representação de uma conformidade plena na forma de uma asssíntota, o dever e a busca da santidade Ihe apareceriam na sua irrealidade.

Reinstaura-se, portanto, a oposiçăo entre, de um lado, o conflito da vontade pura com a vontade sensivel e a realidade efetiva, na Analítica, e, de outro, a unidade necessária apriori desses opostos no sumo bem a ser indefinidamente fomentado, na Dialética, a qual năo mostra como eles estão unidos na determinação da vontade e no agir moral cindido entre vontade pura e sensivel; reinstaurase, também, a oposição entre a heterogeneidade total da moralidade e da felicidade, na medida em que aquela é condição negativa da autonomia moral, por um lado, e a sua integraçăo sintética mediante o agir moral em vista da realizaçăo do sumo bem no mundo, por outro. Hegel vai interpretar essa progressão indefinida na realizaçăo do sumo bem como o deslocamento indefinido da perfeição moral projetada no infinito, uma protelação que é expressamente querida e dissimulada pela consciência moral, a fim de que ela possa continuar a ser efetiva enquanto agir moral. $\mathrm{O}$ postulado da imortalidade da alma toma-se função desse deslocamento recorrente pelo qual a consciência moral projeta num além nebuloso (aproximaçăo indefinida) a perfeiçăo que ela 'deve' querer e põe como inalcançável. Portanto, "a própria consciência [moral] deciara que não leva a sério a perfeiçāo (Vollenđung) moral, ao deslocá-la e dissimulá-la "em direçăo à infinitude afora" (in die Unendlichkeit hinaus), isto é, ao afirmá-la como nunca per-feita (niemals vollendet)". (439, § 622)

Mas a garantia última do sentido de um progresso moral infinito, que assegure a um ser racional finito a expectação legitima de um aperfeiçoamento ulterior sempre possivel, baseado no progresso anterior do pior ao melhor, e, também, "a esperança confortante, embora não a certeza" de uma participaçăo na santidade, graças à "consciência de uma disposição de ânimo [moral] comprovada", exige mais, todavia, do que o postulado da imortalidade da alma. Ela exige além da 
hipótese da imortalidade da alma, a hipótese de um entendimento infinito, legitimada pelo postulado do 'sumo bem originário' como autor da natureza, "para o qual a condiçăo do tempo nada é, e [que] vê nesta série, para nós sem fim, a conformidade integral (das Ganze der Angemessenheit) com a lei moral". (KpV A 221) $\mathrm{O}$ que converte este aperfeiçoamento moral meramente assintótico da criatura numa esperança fundada de alcançar na "infinitude da sua perduração", "mesmo para lá desta vida" (KpV A 222), esta 'conformidade plena' da sua disposiçăo de ânimo à vontade divina, é a sinopse apriori da série progressiva, para nós indefinida, num inteligência infinita, para a qual 'a condição do tempo nada é' (KpV A 226) e perante a qual "esta meta afastada até ao infinito afora" (ins Unendliche hinausgerücktes Ziel') "vale como posse" (id., A 222). Mas o que Kant pode pensar como conformidade integral, apesar de assintótica, mediante a hipótese de uma inteligência infinita, ratificada praticamente pela crença racional na existência de um arquétipo originánio da santidade, e por analogia com a análise infinitesimal, ${ }^{23}$ - a distância que impede que a tangente toque a curva no infinito torna-se sempre menor, podendo ser, ao fim, negligenciada, - permanece para Hegel a representaçẩo praticamente contraditória de uma 'tarefa absoluta'.

É a irredutibilidade do duplo ponto de vista, do finito e do infinito, junto com a distinçăo transcendental entre fenômeno e coisa em si, o alvo último da crítica de Hegel ao tipo de resolução das antinomias da razâo pura (teóricas e prática). Hegel insere a distinçăo e a frredutibilidade desses dois pontos de vista no interior da própria autoconsciência moral, da qual elas passam a ser momentos, de modo que o postulado do 'sumo bem originário', como 'telos' prático do aperfeiçoamento infinito, perde a sua validade objetiva e se reduz a uma projeçăo recorrentemente deslocada pela consciência moral, que a ela recorre para manter a ilusão necessária do seu progresso moral. Ao termo de sua experiência através desta série de deslocamentos a 'tarefa absoluta' do aperfeiçoamento moral ao infinito mostrar-seá como uma contradição prática para a própria consciência moral: ele é uma tarefa que deve permanecer tarefa ('progresso indefinido') e, contudo, ser pensada na sua consumaçăo ('o todo da conformidade') para năo perder o seu sentido. Por isso, a implicação do postulado da existência de Deus pelo postulado da imortalidade da alma e a passagem kantlana do "sumo bem derivado", enquanto objeto real necessário da vontade, ao postulado da existência do "sumo bem originário", permanecem para Hegel encerradas no pensamento representativo da consciência moral que năo apreendeu o seu conceito.

A critica de Hegel repousa, além disso, sobre a transformação semântica a que ele submete o conceito kantiano de postulado, assinalada por M. Guéroult. ${ }^{24}$ Os postulados kantianos săo proposiçōes teóricas que afirmam a existência das "condições fisicas e metafisicas ... insitas na natureza das coisas" (KpV A 258), que tornam praticamente possivel a realização do sumo bem no mundo, enquanto

23 Philonenko, A., Reeflexion sur la doctrine kantienne des postulats de la ratson pratique, In: Philonenko, A., Mótaphysique et Politique chez Kant et Fichte, Paris, Vrin, 1997, p. $72-75$.

24 Guéroult, Martial, Les "déplacements" ("Verstellungen") de la conscience moral kantienne selon Hegol, In: Bds. Vários, Hommage a Jean Hyppolite, Paris PUF, 1971, p. 74. 
objeto total da vontade e fim-último da razão prática. Eles são explicitados por uma reflexăo transcendental como condições de possibilidade não da própria experiência moral como fato último da razão, mas da sua consistência, isto é, da compatibilidade, assegurada praticamente em seu fundamento ontológico último pela existência de um autor da natureza, entre a autonomia moral e a realização da felicidade do gênero humano, a que ele faz jus pelo seu agir virtuoso. Em Hegel, entretanto, a dedução transcendental do conceito de sumo bem e a reflexão transcendental sobre os seus pressupostos práticos tornam-se momentos estruturais da própria experiência da consciência moral, de modo que a validade objetiva dos objetos postulados e a existência dos seus objetos como conteúdo de uma crença racional fundada praticamente são para Hegel apenas uma representaçăo, uma 'visão moral do mundo', derivada da contradição interna da consciêncja moral e construida pelos seus deslocamentos que desdobram essa contradiçāo. Há, portanto, um nivelamento dos dois registros, como observou Stanguennec, ${ }^{25}$ que para Kant permanecem irredutiveis: o registro da certeza apoditica da lei moral e o da reflexăo filosófica sobre as condiçōes de possibilidade do objeto que a lei ordena a vontade fomentar, ambos, agora, em Hegel, transformados em conteúdos da experiência da consciência moral enquanto figura transitória do espírito. Com isso se abolem, para Hegel, as fronteiras irredutiveis entre Analitica e Dialética da Crítica da Razāo Prática, assim como o "abismo intransponivel" entre liberdade e natureza, e a diferença ontológica última entre puro dever e realidade efetiva. Bsta última diferença já está para Hegel ultrapassada na identidade em si desses opostos, implicada pela consumação do dever como "fim total" na realidade efetiva da natureza transformada pela ação moral, ação essa que é, ao mesmo tempo, "ação moral pura" (realizaçăo efetiva da determinação imediata da vontade pela forma da lei) e realizaçăo efetiva vontade singular, que se objetiva no fim atualizado e tem a fruiçăo de si na consciência dessa sua autorealização. (426, § 602) As fronteiras irredutiveis entre Analitica e Dialética são ultrapassadas na experiência que a consciência faz da sua contradição e dos sucessivos deslocamentos pelos quais ela se objetiva e se projeta na visăo moral do mundo, para apreender, ao termo da experiência dessa objetivaçāo, o seu conceito.

Mas desse deslocamento recorrente da santidade como meta do progresso moral, da reposição continua da vontade sensivel avessa ao dever e do renascimento de uma natureza sempre rebelde ante a sua sujeiçāo à liberdade, resulta, ao termo da experiência que a consciência faz desse progresso ao infinito, a sua imperfeição essencial. "Não há autoconsciência efetiva moralmente perfeita." $(433$, § 613) O resultado é a negação da pressuposição inicial de que havia uma consciência moral efetiva, pois, agora, ela só é efetiva num "estado intermediário de nẫoperfeição". (ibid.) Resta-Ihe a desarmonia e a separação da consciència do dever $e$ da sua realidade efetiva, isto é, a sua imperfeição intrínseca. Ao mesmo tempo, porém, a consciência moral não pode permanecer estacionária, a meio caminho. do juizo, traduçăo de Valério Rohden e António Marques, Rio de Janeiro, Forense Universitátria, 1993, D. 20. 
Da simultaneidade dessa exigência de um aperfeiçoamento constante, que reduziria a resistência da natureza interna e externa progressivamente a zero, e da oposiçåo, essencial à moralidade, entre vontade pura e sensivel, entre liberdade e natureza, resulta paradoxalmente para esta consciência moral, agora essencialmente imperfeita, que o crescimento $\theta$ aproximaçăo progressiva da sua meta é, ao mesmo tempo, uma diminuição da moralidade e uma aproximação continua da sua supressăo: o que para Kant é o aumento constante da "autocracia", no sentido do reforço da virtude e da perseverança no progresso moral, que tende a reduzir a resistência da sensibilidade a zero, torna-se para Hegel uma progressão ao avesso, uma 'diminuição' crescente em direção à supressăo da pressuposiçăo essencial da própria consciência moral, que é a oposição entre razāo e sensibilidade, dever 8 realidade efetiva. Além do mais, os impulsos e desejos são elementos constitutivos da ação moral concreta, os quais, uma vez eliminados, suprimiriam também esta. (439, § 623) A conclusão é que, em face da sua imperfeição essencial e da desarmonia entre moralidade e felicidade no mundo, a consciência moral não leva mais a sério a busca da sua perfeição, de cujo perpétuo deslocamento ela se toma consciente, retornando, assim, ao seu ponto de partida, que era a projeção da harmonia num além inefetivo. (439, § 624)

Essa imperfeiçăo constitutiva da consciência moral faz, agora, desaparecer a exigência da felicidade como 'merecimento' (Verdienst) e como retribuiçāo racional por algo de que aquela teria se tornado digna. Consciente da sua imperfeiçăo essencial e da sua indignidade, ela não pode mais considerar a sua felicidade como necessária, mas só como contingente. Năo há mais virtude enquanto "fundamento absoluto" de uma felicidade que the seria proporcional, e esta só pode ser esperada como uma 'graça livre' (440, \$ 624) do acaso ou do arbitrio de uma generosidade amiga. A consciência moral que assume a sua finitude moral e a sua imperfeiçăo reconhece entäo explicitamente que ela não pode mais postular a felicidade como retribuiçăo a algum 'merecimento'; ela só pode esperar "a felicidade enquanto tal, em si e por si", e não mais uma felicidade baseada "no motivo absoluto" do mérito.

Se só há efetivamente consciências morais imperfeitas, que não podem obedecer plenamente à lei moral nem sabê-lo se o fazem, o que desaparece mais radicalmente é o próprio sentido de um critério de dijudicação moral, que permitiria julgar a qualidade moral do agente, condenar a desarmonia entre moralidade e realidade efetiva e enunciar o juizo de experiência: o homem moral sofre injustiça no mundo e o imoral é feliz. Este enunciado é, agora, deslocado, pois ele năo é senão a dissimulaçăo do fato de que não há verdadeira consciência moral. Com efeito, se o agir só se deixa concernir pela felicidade como tal, é arbitrário afirmar que alguém mereceria do curso do mundo outro tratamento que o que lhe é de fato dispensado, desaparecendo a base para qualquer juizo de retribuição que não seja arbitrário. "O que pode acontecer de moralmente mau na experiência (para uma tal consciência essencialmente imperfeital?" (440, § 625) Hegel conclui implacavelmente desta desarmonia final entre a moralidade e a felicidade que a queixa do justo é arbitrária e que o fundamento do juizo de experie̊ncia desta consciência, tornada năo-motal, são apenas os sentimentos do queixoso: é "a 
inveja que se cobre com o manto da moralidade" que julga que a felicidade como tal năo deveria ser o quinhão de alguns. Só resta a "boa amizade", prestes ou năo a desejar e conceder a si e aos outros esta "graça" como um "acaso". (440, § 625)

\section{5- O postulado do "sumo bem originánio" como "santo legislador"}

\section{a) A gênese do postulado do "santo legislador"}

A única maneira de superar a contradição entre o ponto de partida, a pressuposição de que existe uma consciência moral efetiva, e o resultado da dialética dos dois postulados anteriores, 0 de que não existe uma consciência efetiva que seja moral, portanto, entre uma consciência moral que se revela essencialmente imperfeita e impura e a sua essência moral perfeita, deslocada para o progresso ao infinito, é que a consciência moral projete, por um novo deslocamento, a perfeiçâo moral numa outra consciência transcendente, que, como "arquétipo da perfeição prática" (KpV A 230), seja a garantia de que o progresso moral tenha sentido para a consciência moral imperfeita. $O$ dever de fomentar indefinidamente o sumo bem no mundo, que implica para Kant o postulado da existência do "sumo bem originário" (Deus) como fundamento da possibilidade de que o sumo bem possa ser realizado pela ação moral (KpV A 226), resulta para Hegel da 'transposição para fora' (hinaussetzen, 445, § 632), num além da consciência moral imperfeita, do seu saber da pura moralidade como sendo a sua esséncia, que ela agora pensa como realizada perfeitamente numa consciência transcendente. ${ }^{27}$ Esta assume a figura do 'santo legislador moral', o arquétipo da santidade $(441, \S 626)$ que, para Kant é um dos três predicados morais, funtamente com a sabedoria e a bem-aventurança, que podem ser analogicamente atribuidos de maneira exclusiva a Deus (KpV A 236), mas que para Hegel representa tăo só a resolução das contradiçōes e deslocamentos dos dois primeiros postulados numa sintese mais alta, que, agora, reúne e integra as harmonias anteriormente postuladas. Esta síntese superior contém a harmonia 'em si' da moralidade e da 'natureza objetiva', que constitui 'o fimúltimo do mundo', e a harmonia 'para si' da moralidade e da vontade sensivel (a natureza dada no sentido interno), que constitui 'o fim-último da autoconsciência.

27 A reconstruçắo genética, empreendida por Hegel, do pcetulado do santo legisiador como uma tepresentação projetiva que a consciência moral imperfeita faz do seu saber de que o puro dever é a sua esséncla num em-sí transcendente, nåo é senão uma radicalizaçăo critica de díficuldade, já visivel em Kant, de justificar racionaimente na filosotia critica por que a virtude näo recompensada por uma felicidade da qual ela teria se tornado digna, e mais basicamente, por que o fracasso da tealizaçăo progressiva do sumo bem no mundo é algo inaceittavel "no juizo de uma razäo imparcial" (KpV A 199). Por que o mérito de ter agido virtucsamente e de ter se empenhado na realizaçlo do sumo bem cria o direito a uma expectaçào indenegável de participar na feilcidade, fá que a vontade é moral quando é determinada exclusivamente peia forma da les, independentemente de todo elemento material, que so pode ser reintroduzido modiante o postulado da existéncia de Deus? Por que a necessidade prática de fomentar o sumo bem, "conexa com o dever enquanto exdgẻncia (Bedilfnis) de pressupor a sua possiblidade", que por sua vez exige a pressuposiçlo da exdstência do sumo bem originúrio, liga indisschuvelmente a pressupcsiçâo dessa existência com a leị mcral? (KpV A 226) Bssa Hgaçấo indissolúvel para Hegel năo esta fundada na prớpria consciência moral, como pretende Kant, e é fruto da representaçấo projetiva da consciência motal imperfeita. 
(429; § 604) O postulado da existência do 'sumo bem originário' como 'santo legislador' integra, assim, as duas formas anteriores de harmonia numa harmonia 'sendo em si e para si', que para nós, a reflexảo fenomenológica, nada mais é do que a mediação imanente ao próprio agir moral efetivo projetada numa consciência transcendente, que, como objeto do puro pensamento postulativo, nâo é ainda conceitualmente apreendida na sua identidade com aquele agir efetivo. (432, § 611) Mas agora os momentos opostos dessas harmonias anteriores, o puro dever e a realidade efetiva, que até então não eram ainda, na sua diferenciação abstrata, objeto para a consciência, entram efetivamente em cena para a própria consciêncja como sendo cada um o oposto do seu outro e como "postos numa unidade", na qual estảo suprimidos e superados (aufgehoben) como momentos. (431, § 610) Nisso a consciência moral sabe que a visăo moral do mundo chegou ao seu termo (ist vollendet), embora ela năo esteja ainda ciente de que esta última não é senão o desenvolvimento e a objetivação do seu conceito. (432, § 611)

O puro pensamento que postula a existência de um 'sumo bem originário' apenas 'representa', portanto, num ente transcendente, a sintese do fim-último do mundo (objeto do 'primeiro' postulado) e do fim-último da autoconsciência moral enquanto tal (objeto do 'segundo' postulado), cuja raiz é a mediação entre puro dever e realidade efetiva, contida no agir moral, que funda como termo-médio a sintese daquelas harmonias projetadas. $(429, \S 604)$ Mas a existência de um sumo bem originário 'representa', também, a resoluçăo da contradiçăo entre o ponto de partida (1) e o resultado final (2) das dialéticas dos dois primeiros postulados: 1) "há uma autoconsciência moral efetiva", cujo si-mesmo (Selbst) está em unidade imediata com conformidade de toda realidade efetiva ao dever, mas que, como consciência, 'representa' essa unidade imediata (harmonia) como um objeto, que é só 'pensado' como sendo necessário e é só um negativo além de toda a realidade efetiva ( 432-433, § 612); 2) "nâo há uma autoconsciêncla moral efetiva perfeita", pois, em face dessa harmonia representada como objeto transcendente, só the resta a consciência da desarmonia entre a consciência do dever $e$ a sua realidade efetiva; mas, visto que a moralidade consiste somente na conformidade ao puro dever e, portanto, tudo o que é real-efetivo é não-moral, segue-se que "não há algo moralmente efetivo", de sorte que também a harmonia postulada perde o fundamento. (433, § 613) Dilacerada entre o puro pensar do dever, que é inefetivo, e a sua realidade efetiva, que nāo é moral, esta autoconsciência contém, contudo, no seu si-mesmo (Selbst) a unidade em si desses momentos opostos, que ela por isso vai representar sob a forma de uma perfeição transcendente que lhe é essencial, e que, estando além da realidade efetiva, deve, contudo, ser efetiva. (433, § 614)

Além de encaminhar a resolução da contradiçăo entre o ponto de partida e o resultado das dialéticas anteriores, o postulado da existência de 'um senhor e soberano do mundo' (430, § 606 ) tem a função primordial de estabelecer a mediação entre o "saber e querer simples do puro dever" e a multiplicidade dos deveres, oriunda da relação necessária do agir moral a uma realidade efetiva multiforme. A consciência moral năo apreende conceitualmente que a mediaçăo entre o puro 
dever (o universal, a forma) e os múltiplos deveres (o particular, ${ }^{28}$ o conteúdo) já está presente no seu próprio agir moral, e por isso, inicialmente, para ela enquanto consciência, só é válido nos múltiplos deveres aquilo que é puro dever, e, ao mesmo tempo, enquanto agir moral, por causa da sua relaçăo à realidade efetiva das várias situações, ela se confronta necessariamente com múltiplos deveres determinados, que são também igualmente válidos na sua diversidade. $(429, \S 605)$ Para resolver esta oposição entre unicidade e multiplicidade, forma e conteúdo do dever, ela projeta, alternativamente, na consciência transcendente do 'santo legislador', ora a validação ("santificaçăo") dos múltiplos deveres, quando para ela só é essencial o dever simples e puro, ora, inversamente, a validaçăo ("santificaçăo") do dever enquanto tal, uno e único, quando para ela, como consciência moral singular, o essencial é o agir moral no conteúdo múltiplo dos seus fins particulares. $(430, \S 606) \mathrm{O}$ conceito dessa consciência transcendente, em que forma $e$ conteúdo, universal e particular, săo um, é idêntico com o conceito do sumo bem originário. ${ }^{29}$ Hegel recupera criticamente, aqui, mediante esta gênese, a passagem kantiana da moralidade à religião (KpV A 233), pela revalidaçăo dos deveres enquanto mandamentos de uma vontade legisladora soberana. ${ }^{30}$

28 O particular, aqui, não é maís o impulso como conteúdo empirico que medeía a realizaçĩo do dever, mas o 'dever determinado', 'a determinidado no dever determinado'. (430, s 606)

29 "Postula-se assim que haja uma outra conscléncia, que santifique os múltiplos deveres, ou que os saiba e queira como deveres. A primeira consciéncia mantem o dever puro [como] indiferente ante todo canteúdo determinado, e o dever é somente essa indiferença para com o conteúdo. Mas a outra consciêncla |transcendente| contém a relaçảo igualmente essencial para com 0 agir $\theta$ a né. cessidade do conteuido determinado. Como os deveres tềm valor para essa consciẻncia como deveres determinados, por isso o conteúdo the é tho essencial quanto a forma, graças à qual o conteúdo é dever. Por conseguinte, essa conscièncta é uma consciència em que o universal e o particular sẫo simplesmente um; e seu concaito é, assim, o mesmo que o conceito da harmonia da mora. Udade e da fellcidade. (Phän, p. 430, § 606, trad. de Paulo Meneses, minimamente modificada, pots parece-me melhor traduz's heiligen por 'santificar' do que por 'consagrar', a fim de manter a proximidade com o atributo do 'santo legistador'.

30 Neste ponto preciso Hegel parece náo levar suficientemente em conta a ênfase de Kant na autarquila fundacional da lei moral na razão pura prática, da qual decorre o dever de tealizar o sumo bem no mundo e, mediante este conceito, 0 'conhecimento' dos deveres como mandamentos divince, que ndo faz do 'criador santo' e da vontade a ele atribuida apenas hipoteticamente, por analogia com as nossas faculdades, o fundamento da própria lei moral e da sua validade. (KpV, A 233) Nem as leis morais precisam ser sancionadas ou santilicadas como ordens arbitrárias de uma vontade onipotente para serem válidas, nem o postulado da existência de um "sumo bem origináno", "cause suprema da natureza" (KpV 226), é propriamente a garantia da realização do sumo bem no mundo, pois ele só enuncia, hipoteticamente, por analogia, o fundamento da possibilidade ontológica da convergéncia entre natureza e liberdade, que a promoçăo do sumo bem pelo agtr moral finito pressupőe. Yirmiyahu Yovel, Kant et la Philosophie de l'Histoire, Paris, Méridiens Klin. sleck, 1969, p. 82-85. Em contrapartida, o conteùdo dos postulados, enquanto objeto de uma crença racional, nåo è moralmente ordenado, pois eles enunciam as condiçóes, "fisicas e metafisicas", logicamente derivadas do dever de promover o sumo bem ordenado pela lef moral, que asseguram que a sua realizaçĭo no mundo pelo agir humano é possivel.

Labarrière chama a atençảo para o fato de que esta consciência absoluta do santo legjislador $e$ posta como exigênça da consciència moral e em função deia, e que, portanto, ela nảo significa a pessagem especificamente hegeliana à religtăo, a qual implica a "autoconsciência da essência absoluta', tal como esta existe em si e para si. Phénoménologie de l'Esprit, trad. Plerre-Jean Labarrfère, Paris, Gailimard, 1993, p. 534, Nota 1. 
b) Os deslocamentos do pcstulado do 'santo legislador' e a sua contradição interna

A consciência moral efetiva, que ao final da dialética anterior 'colocara' a sua imperfeiçăo essencial, sabe, contudo, que a essência da moralidiade é a perfeiçăo pura, e por isso a projeta na consciência transcendente do 'santo legislador moral', na qual ela 'representa' a unidade postulada do dever e da realidade efetiva e, ao mesmo tempo, a supressão da sua desconformidade com o dever. (431-432, § 610) Na sua relação à realidade efetiva 'outra' de uma natureza dada e estranha, essa consciência imperfeita se fragmenta numa multiplicidade de deveres, que ela considera, todavia, inessenciais em face da sua consciência do dever puro e simples, e da moralidade perfeita do santo legislador. Por isso, eles so podem tornarse verdadeiros deveres para ela na medida em que são queridos por este. Mas esta validação externa se revela, em seguida, um novo deslocamento, pois a autoconsciência moral sabe que a sua autonomia é 'o absoluto', e que para ela só é dever o que ela sabe como tal. Portanto, o que não é fruto da sua autolegislação e intrinsecamente válido não pode ser extrinsecamente santificado peio legislador. A autoconsciência que se sabe autônoma nåo mais levará a sério, assim, nem essa santificaçâo externa, nem a própria santidade do sumo legislador, pois como poderia ser validado como essencial o que para a sua consciência autônoma do dever absoluto năo o é? A validaçăo ('santificaçăo') externa e o própria figura do santo legislador são, portanto, deslocados pela autonomia moral consciente de si, antecipando a próxima figura do espírito que é a 'certeza-moral' (Gewissen). (441, § 626)

Mas se o santo legislador é postulado como fonte e instância de validação dos múltiplos deveres determinados, seria preciso novamente deslocar essa representaçăo, pois como o cumprimento dos deveres pela ação da consciência imperfeita é perpassado pela conviç̧ão singular e contingente do que é em cada situação o dever determinado, ela tem agora, inversamente, de projetar no santo legislador a validação do que há de absoluto no dever determinado e de representar o legislador transcendente como a fonte única da validade do puro dever. $(441, \S 627) 0$ dever só é sagrado para a consciência moral agente na consciência do "santo legislador do puro dever". (431, § 607) Este deslocamento significa que o legislador só é santo porque é a única instância graças à qual o puro dever tem validade e que, por isso, valida a abolutidade do dever no dever determinado. Portanto, como para a consciência moral imperfeita a moralidade revela-se uma contingência da vontade e do saber, visto que a vontade pode infringir a lei moral, e o saber do dever determinado pode ser incompleto e contingente, a moralidade acabada só existe na consciência transcendente do santo legislador. (ibid.)

Após esse duplo deslocamento, que ora incumbe o legislador transcendente de validar o dever determinado para a consciência do dever puro e simples, ora de validar este para a consciência imperfeita que age e efetiva o conteúdo do dever determinado, esta se dá conta de que esta alternância apenas dissimula a sua própria contradição, pois a sua imperfeição consiste numa relação positiva necessária à natureza e à sensibilidade, enquanto estas são momentos essenciais implicados no agir moral, com os quais, ao mesmo tempo, ela só tem, contudo, pura e 
simplesmente uma relaçāo negativa. Mas esta contradição se insinua agora na própria consciência transcendente do santo legislador, pois ele năo pode ter nem uma relaçăo negativa nem positiva com ambas: como arquétipo da "moralidade puramente acabada", ele não está mais em oposição e em luta com a natureza e a sensibilidade, portanto, em relação negativa a elas, que constituem, todavia, um momento essencial realizaçăo efetiva do puro dever pela ação, e nem pode estar numa relaçăo positiva elas, pois esta envolveria, precisamente, uma imperfeição moral, de sorte que aquela moralidade acabada termina por revelar-se ou "inefetiva e abstrata" ou "carente-de-consciência". (442, § 628)

Esta argumentaçăo por disjunção pretende mostrar a contradiçăo interna do próprio conceito de 'moralidade acabada', pois a perfeiçăo da natureza e da sensibilidade plenamente conformadas ao puro dever a colocaria 'acima' de uma relação oposta à natureza e à sensibilidade, que é a única que pode dar realidade efetiva e consciência à moralidade. Uma "moralidade em si e para si" seria, a um só tempo, a moralidade de uma consciência, que se sabe determinada pela forma da lei (moralidade para si), e a moralidade que tem realidade efetiva no seu agir (moralidade em si). (443, § 630) "A sua verdade [da moralidade acabada] deve consistir em ser oposta à realidade efetiva, e totalmente livre dela e vazia, e nisso, de novo, ser realidade efetiva". (444, § 630) Projetada, como tal, no santo legislador, ela se revela, ao fim, um novo e último deslocamento dissimulador da contradiçāo da consciência moral. Para a consciência que sabe disso, a figura do santo legislador tem de ser abandonada, assim como o próprio conceito de moralidade, definido pela simultaneidade do pensar e querer do puro dever (pureza e validade formal absolutas) e do querer e saber concretos do agir moral que efetiva o dever (realidade efetiva). $O$ 'autor santo e bom do mundo' (KpV 233), que já para Kant tendia a tornar-se mera função da crença racional na possibilidade da realização do sumo bem no mundo, é reduzido por Hegel a uma projeçăo inconseqüente da autoconsciência moral que năo apreendeu o seu conceito e a sua contradiçăo. Hegel retoma e radicaliza aqui a crítica kantiana à metafisica dogmática, mostrando que a teologia moral dos postulados, fundada em última análise numa autonomia formal que separa o puro e o empírico, a validade e a realidade efetiva, é ainda um prolongamento daquela.

\section{6 - Conchusăo}

Com o deslocamento final e o colapso do postulado do santo legislador, pensado como a essência transcendente da moralidade acabada e como a resolução teológico-moral da contradição da consciência moral, completa-se a visăo moral do mundo, pois, agora, a autoconsciência moral vai intuir neie o seu próprio conceito, quer dizer, ela vai descobrir que o seu saber do puro dever e o puro pensar da moralidade acabada săo idênticos no seu si-mesmo. Mas ela ainda năo apreende esse conceito como tal, pois ela intui sob forma ainda objetiva a unidade dos opostos antes separados, o puro dever e a realidade efetiva (sua e da natureza), a validade formal e o agir concreto, entre os quais ela oscila e o "representar sintético" dos postulados "vagueia" (sich herumtreibt). Nessa intuição da unidade dos opostos ela retorna à sua contradição fundamental entre consciência formal da 
validade absoluta e realidade efetiva da sua açầo e da natureza, só que agora os momentos dessa contradição "se aproximam tanto [...] que a consciência tem de, aqui, abandonar a sua visăo moral do mundo e de se refugiar adentro de si". (442, § 629) Porém só através da experiência da contradiçăo interna do terceiro postulado e do colapso da visão moral do mundo objetivada, experiência que a autoconsciência moral faz ao fim dessa série de deslocamentos que a conduziram até completo o refluxo em si mesma, é que ela poderá apreender a sua contradiçăo fundamental como sendo a matriz da projeção da moralidade acabada no santo legislador, e, assim, apreender neste, enquanto 'seu contrário absoluto', a sí mesma: ao reconhecer no objeto da sua projeção o seu si-mesmo, ela apreende o seu 'conceito absoluto'. (432, § 611)

Inicialmente a consciência moral năo se dava conta de que a sua visão moral do mundo, que se desdobra e articula pelos deslocamentos dissimuladores da sua contradiçăo fundamental, não era senão o desenvolvimento e a objetivaçăo do seu próprio conceito. De inicio, ela não apreende como tais nem a oposição segundo o conteúdo (puro dever - realidade efetiva, autonomia formal - natureza, validade agir), nem a oposição segundo a forma (consciência imanente - consciência transcendente). Por isso ela é, antes, "propelida" e arrastada pelo movimento vertiginoso e enganador dos deslocamentos e não é capaz de reconhecer no puro pensamento dos postulados (que para Hegel é representativo, e ainda não conceitual) o movimento pelo qual ela objetiva o seu próprio conceito e projeta a resoluçăo representativa das suas contradições. Só ao termo da experiência da contradição interna do santo legislador como encarnação da 'moralidade puramente acabada' é que consciência moral, ciente ao mesmo tempo da sua imperfeiçăo essencial e de que o puro dever é, todavia, a sua essência, é que ela pode apreender esse "seu contrárlo absoluto como si-mesma". $(432$, § 611) Nós, a reflexão fenomenológica, sabemos que o périplo completo da experiência dos deslocamentos nada mais é do que o desenvolvimento do conceito da autoconsciência moral, desenvolvimento mediante o qual ela se objetiva nessa visão moral do mundo, que agora se revela no seu todo como "o sincretismo dessas contradiçōes". (443, § 631) Mas ela só toma consciência disso ao termo desse périplo, através do qual ela "apresenta" (darstellt) o que ela é, ao se defrontar com a condensação das suas contradiçöes e dos seus deslocamentos na contradição interna da figura do santo legislador. Como representação da moralidade perfeita (a 'essência absoluta' da santidade), ele é a síntese 'em si e para si' do fim-último objetivo (harmonia da moralldade e da realidade efetiva da natureza) e do fim-último subjetivo (harmonia da moralidade e da sensibilidade) $(429, \S 604)$, que deve ser pensada como estando além da realidade efetiva, e, contudo, como real-efetiva.

Nesta figura os desdobramentos anteriores da contradiçăo fundamental da consciència se condensam e aguçam numa oposiçăo máxima entre a moralidade perfeita, pensada como necessária e posta como em-si numa consciência transcendente, e o si-mesmo (das Selbst) da consciência moral imperfeita, que sabe, contudo, que essa pura moralidade é a sua essência, mas que, faz, agora, a experiência de que esta diferença entre ambas as consciências opostas é nula e puramente verbal. (443-444, § 631) A autoconsciência moral reconhece, então, que a 
'contradiçăo segunda a forma' entre o em-si da moralidade acabada e o si-mesmo da consciência imperfeita que sabe contudo o puro dever como sua essência, não é senão a "transposição para fora de si mesma" (a projeçāo), na figura do santo legislador, daquilo que ela tem de pensar como sua "contradição segundo o comteúdo', a saber, que a validade absoluta do dever é um além inefetivo da consciência, que contudo, só "tem lugar" e é efetivo nela. (445, § 632) Assim, tanto o puro saber da validade absoluta do dever, quanto o puro pensar da moralidade perfeita com um além da consciência efetiva imperfeita, se revelam, ao fim, para a consciência fenomenológica ("para nós"), como expressões idênticas do si-mesmo dessa consciência moral imperfeita: graças a esta identidade sabida de ambas com o seu próprio si-mesmo efetivo, ela retorna a si e sabe, também, agora, que ela, na sua singularidade contingente è o "puro saber e o puro agir", contendo em si suprassumida a oposição entre puro dever e realidade efetiva. ${ }^{31}$

Nesta experiência que a consciência moral faz de que a oposiçã̃o entre ela enquanto imperfeita e a consciência transcendente se resolve na única e mesma realidade efetiva do seu si-mesmo, a "pura autoconsciência moral" (moralisches reines Selbstbewusstsein) se torna "pura boa-consciência" ou "pura certeza moral de si mesma" (reines Gewissen) que tem na sua "autocerteza" (Selbstgewissheit) e na convicção absoluta que preside ao seu agir efetivo o conteuido do dever que the era antes vazio. (446, § 633) O seu conceito năo é mais deslocado e dissimulado na figura do santo legislador, mas é apreendido como tal no poder que ele tem sobre este objeto transcendente, este 'seu contrário absoluto apreendido enquanto si mesmo'. (432, § 611) A autoconsciência moral se vê, assim, obrigada a reconhecer que ela nâo mais pode levar a sério a "extraposição mútua" (Auseinanderstellung) dos momentos que sustentavam a visão moral do mundo, de um lado o em si da moralidade perfeita como um absoluto fora da consciência, que ela agora sabe que é "uma coisa-de-pensamento irrealizada", e, de outro, o si-mesmo da sua autoconsciência, que igualmente sabe que aquele em si está incluso nela. Por conseguinte, ela também não leva mais a sério separaçăo dos termos opostos que articulavam a contradição do seu ponto de partida (o puro dever e a realidade efetiva, a Gesinnung e o agir, a vontade pura e a sensivel, a autonomia formal e a natureza etc.), separaçăo que é condiçăo para a justificaçăo da tese central da Analítica, de que a razão pura é prática por si mesma porque se determina a si mesma como vontade pura unicamente pela forma da lei. Compelida pelo colapso da visåo moral do mundo, a autoconsciência moral reconhece, entăo, que a superaçăo desses dualismos e da diferença ontológica entre liberdade e natureza, mediante o postulado de um santo legislador que é autor do mundo e da lel moral, já estả contida

31 "Mas porque o que aparece como contraditório, e em cuja separaçăo e resoluçăo reiterada a visăo moral do mundo vaguefa e se debate, é em si, prectsamente, o mesmo, a saber, o dever puro corno puro saber nâo ê outra coisa que o si-mesmo da consctência, e o si-mesmo da consciéncia é o ser o [a] realidade efetiva, - [porque] jgualmente o que deve ser além da consciência real-efetiva nầo é outra colsa que o puro pensar, portanto, de fato, é o si-mesmo, assim a autoconsciência, para nós ou em si, retorna a si, e sabe como si mesma aquela essêncla na qual o resl-efetivo é ao mesmo tempo puro saber e puro dever. Essa autoconsciéncta é para si mesma o que é plenamente-válido (das Vollgultige) na sua contingência, o que sabe a sua singularidade como puro saber e agir, como a verdadeira realidade efetiva e a verdadeira harmonia." (445, § 632) (trad. de P. Meneses modificada). 
no agir efettivo da autoconsciência, que agora fez a experiência dessa mediação imanente como a matriz daquela sintese (projetada na consciência transcendente) entre fim último do mundo e fim-último da autoconsciência, e, assim, acede a essa pura certeza moral que a boa consciência tem de si mesma (reines Gewissen). $(444, \S 631)$

Com isso torna-se agora também explicito para a autoconsciẻncia que a própria "extraposição mútua" dos opostos, que está na base dos postulados, é um deslocamento dissimulador, e que querer, agora, mais uma vez, deslocar e dissimular o todo da visão moral do mundo, que entrementes se revela para ela como um "mundo do deslocamento dissimulador", para fugir dessa "extraposiçāo" dissociadora, seria uma "hipocrisia" (Heuchelei). (434, § 631) Tomada entåo de "horror' (Abscheu) por essa desigualdade entre a representaçăo desse mundo do deslocamento dissimulador que a visão moral do mundo revelou ser, de um lado, e sua essência agora apreendida conceitualmente, de outro, a autoconsciência moral (moralisches Selbstbewusstsein) se refugia na autocerteza da "boa consciência moral" (Gewissen). Esta não invoca mais o puro dever como "padrão de medida vazio" contraposto à consciência efetiva, mas age a partir da sua convicção moral imediata, plenamente válida na sua contingência (nota 31), sem precisar recorrer à mediaçăo representativa dos postulados para alcançar o objeto integral da sua vontade. (446, § 634) Sabendo, agora, explicitamente, que é a separação e a "extraposição" dos seus momentos opostos, - condensada na oposiçāo fundamental (a oposição segundo a forma) entre o em-si da pura moralidade, verdadeira, mas irreal, e o si-mesmo, efetivo, porém moralmente "nulo" (nichtig) por sua imperfeiçăo, - o que faz surgir o deslocamento dissimulador, a autoconsciência moral se defronta, finalmente, com uma alternativa, em que ela não escapa à confissão da sua hipocrisia de base: por uma, é somente através do percurso da série completa dos seus deslocamentos dissimuladores, objetivados na visão moral do mundo, que a consciència retorna adentro de si e, assim, alcança o seu conceito, "apresentado" na visão moral do mundo; por outra, esse retorno a si a enche de "horror por esse mundo do deslocamento", pois ela sabe, agora, que ele é "tão só uma pretensa verdade", que ela, todavia, "tem de (muss) fazer passar por sua verdade", uma vez que ela só chega ao seu conceito através dele.

Desta "antinomia da visão moral do mundo" $(445, \S 632)$ resulta que a hipocrisia é, senāo a raiz da autoconsciência moral, pelo menos, a contraface essencial da sua contradição fundamental, pois é hipocrisia querer manter separados, irredutíveis e não unificáveis os momentos opostos que estruturam o seu ponto de partida e a sua objetivação como visão moral do mundo; mas é igualmente hipocrisia, por causa do horror que a invade ante o saber de que o mundo moral é inefetivo e uma pretensa verdade, dissimuladora da sua contradição, desprezar essa série dos deslocamentos que o fazem surgir, e, assim, negar o percurso mediante o qual, unicamente, ela alcança o seu conceito. É hipocrisia querer manter no si-mesmo da autoconsciência moral que apreendeu o seu conceito a separação dos momentos, que está na raiz dos deslocamentos, mas negar, por horror à "pretensa verdade" da sua objetivação nos postulados, a necessidade de percorrer os deslocamentos que os perpassam, portanto, dispensar a mediação e "desprezar" 
(Verschmähen) aquele deslocamento, é, novamente, externação da hipocrisia, precisamente a primeira. ${ }^{32}$

Os postulados tinham para Kant a funçăo de reunificar, no foco da unidade da razão, de um lado, a separação, estabelecida pela teoria nomológica da Analitica, entre o puro dever e a realizaçäo dos fins humanos determinados, entre virtude $e$ felicidade, entre validade absoluta e realidade efetiva, separação que era a condiçăo da tese da autonomia moral e da sua autarquia fundacional, e de outro, a sua integração sintética no imperativo de realização do sumo bem no mundo, deduzido transcendentalmente, na Dialética, como objeto total e fim-último da vontade autônoma, que implicava a hipótese de um fundamento ontológico último (o sumo bem originário como autor do mundo), que garantisse a superaçăo do abismo intransponivel entre liberdade e natureza, entre validade e efetividade, superação exigida para que a realização do sumo bem pelo agir humano seja possivel. Para Hegel, esta tentativa de unificar posteriormente, mediante a teoria do sumo bem e dos postulados, o que a tese da fundaçăo absoluta de uma lei moral formal como fato da razão exigiu anteriormente manter separados, irredutiveis e nãounificáveis, significa aceitar a separaçăo última entre moralidade e felicidade, entre o puro dever e a realidade efetiva da natureza e da sensibilidade oposta a ele, entre 0 em-si da moralidade acabada e o si-mesmo autoconsciência moral, separações essas que fazem surgir a visão moral como um mundo do deslocamento dissimulador, cuja antinomia obriga a autoconsciência moral a reconhecer a sua hipocrisia e a se superar na nova figura do espirito que é "pura certeza moral de si mesma".

Esta constitui, na arquitetônica da Fenomenologia do Espírito, o "terceiro simesmo" do espírito, que, assumindo a figura da genialidade moral da boaconsciência, antecipadora da "bela alma", tem na sua convicçăo singular absoluta o conteúdo para a universalidade antes vazia do dever, para a universalidade abstrata da vontade geral incapaz de se institucionalizar ("segundo si-mesmo") e para a universalidade formal do direito (a pessoa como o "primeiro si-mesmo" do espirito). (446, § 633) Ao abrir o caminho para a absolutização da autocerteza moral subjetiva, a teologia moral dos postulados antecipa, na perspectiva da sua critica por Hegel, a auto-supressāo da moral.

32 "Mas se esse mundo do deslocamento dissimulador nấo é outra coisa que o descnvolvimento da autoconsciência moral em seus momentos, e por isso ele é a sua tealidade, [e] assim eia nấo vaf tornar-se, segundo a sua essência, nada de diverso pelo seu retornar a si; seu retornar a st é, antes, scmente a sua conscióncta alcançada de que a sua verdade é uma pretensa verdade. A autoconsciência teria ainda sempre de fazế-la passar por sua verdade, já que ela tem de se expressar e apresentar como representaçăo objetiva, mas saberia que isso é somente um deslocamento dissimulador; ela seria, por isso, de fato, a hipocrisia, e esse desprezar tal deslocamento dissimulador já seria a primeíra externação da hípocrisfa." (444, § 631) (trad. de P. Meneses modificada) 